Fabiana Santos Matsumoto

Caracterização das proteínas do saco vitelínico de embriões bovinos Bos indicus 
Fabiana Santos Matsumoto

\section{Caracterização das proteínas do saco vitelínico de embriões bovinos Bos indicus}

Dissertação apresentada ao Programa de Pós-Graduação em Anatomia dos Animais Domésticos e Silvestres da Faculdade de Medicina Veterinária e Zootecnia da Universidade de São Paulo para obtenção do título de Mestre em Ciências

\section{Departamento:}

Cirurgia

Área de Concentração:

Anatomia dos Animais Domésticos e Silvestres

Orientadora:

Profa. Dra. Maria Angelica Miglino 
Autorizo a reprodução parcial ou total desta obra, para fins acadêmicos, desde que citada a fonte.

\section{DADOS INTERNACIONAIS DE CATALOGAÇÃO-NA-PUBLICAÇÃO}

(Biblioteca Virginie Buff D’Ápice da Faculdade de Medicina Veterinária e Zootecnia da Universidade de São Paulo)

$$
\text { T.1840 }
$$

Matsumoto, Fabiana Santos

Caracterização das proteínas do saco vitelínico de embriões bovinos Bos indicus / Fabiana Santos Matsumoto. - São Paulo: F. S. Matsumoto, 2007.

91 f. : il.

Dissertação (mestrado) - Universidade de São Paulo. Faculdade de Medicina Veterinária e Zootecnia. Departamento de Cirurgia, 2007.

Programa de Pós-graduação: Anatomia dos Animais Domésticos e Silvestres.

Área de concentração: Anatomia dos Animais Domésticos e Silvestres.

Orientadora: Profa. Dr ${ }^{\mathrm{a}}$. Maria Angelica Miglino.

1. Saco vitelínico. 2. Western Blot. 3. Proteínas. 4. Alfafetoproteina. 5. Alfa-1 antitripsina. 6. Transferrina. I. Título. 


\section{UNIVERSIDADE DE SÃO PAULO Faculdade de Medicina Veterinária e Zootecnia \\ Comissão Bioética}

\section{CERTIFICADO}

Certificamos que o Projeto intitulado "Caracterização das proteínas do saco vitelínico de embriões bovinos Bos indicus", protocolado sob o $\mathrm{n}^{\circ} 982 / 2006$, utilizando 30 (trinta) bovinos (peças de matadouro), sob a responsabilidade da Profa. Dra. Maria Angélica Miglino está de acordo com os princípios éticos de experimentação animal da Comissão de Bioética da Faculdade de Medicina Veterinária e Zootecnia da Universidade de São Paulo e foi aprovado em reunião de 13/09/06".

(We certify that the Research "Characterization of the yolk sac protein of the Bos indicus bovine embryos", protocol number 982/2006, utilizing 30 (thirty) bovines, under the responsibility of Profa. Dra. Maria Angélica Miglino, agree with Ethical Principles in Animal Research adopted by Bioethic Commission of the School of Veterinary Medicine and Zootechny of University of São Paulo and was approved in the meeting of the day 09/13/2006).

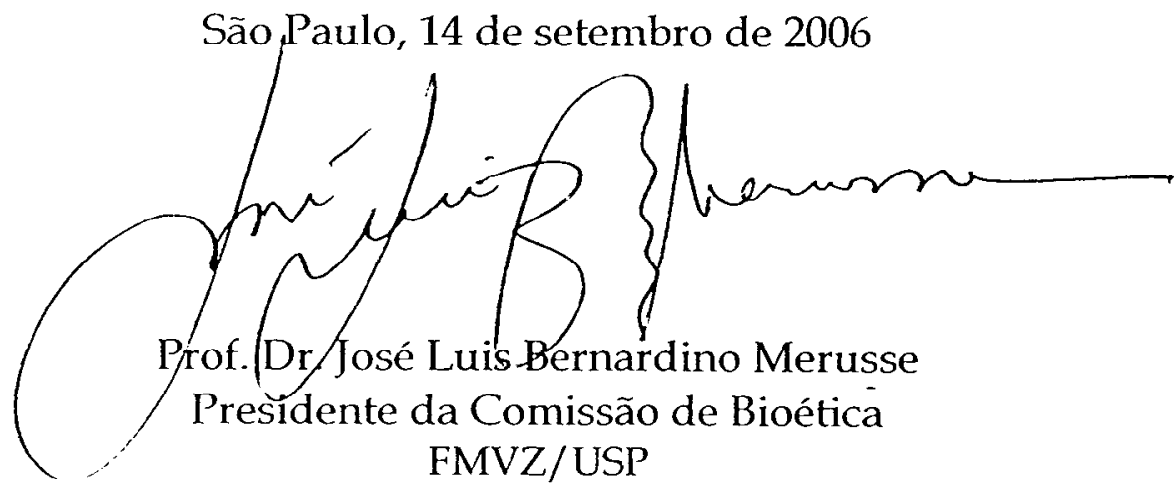

Av. Prof. Dr. Orlando Marques de Paiva, $n^{\circ} 87$ - 05508-270 - Cidade Universitária "Armando de Salles Oliveira". Fax: (11) 3032-2224 - fones: (11) 309107676/7671 - e-mail: fmvz@edu.usp.br 


\section{FOLHA DE AVALIAÇÃO}

Nome: MATSUMOTO, Fabiana Santos

Título: Caracterização das proteínas do saco vitelínico de embriões bovinos Bos indicus

Dissertação apresentada ao Programa de Pós-Graduação em Anatomia dos Animais Domésticos e Silvestres da Faculdade de Medicina Veterinária e Zootecnia da Universidade de São Paulo para obtenção do título de Mestre em Ciências.

Data:

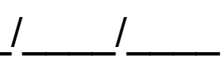

Banca Examinadora

Prof. Dr. Instituição

Assinatura:

Julgamento

Prof. Dr.

Instituição

Assinatura:

Julgamento

Prof. Dr. Assinatura

Instituição: Julgamento 
“Eu aprendi que sou mais forte que imaginava, e que posso ir mais longe depois de pensar que não podia mais, e que realmente a vida tem valor e eu tenho valor diante a vida"

W. Shakespeare 
Taluez esse mamenta represente uma das minhas maiares canquistas, entretanta sei que tuda nãa seria passúuel sem vacês, que sempre arientaram meu caminha. Essa trajetária ficau mais fácil, pais a tada instante tinha a certeza que padia cantar cam vacês. Dedica essa canquista a vacês, nãa sá pela presente de vida, mas principalmente par ensinar a vivê-la. Obrigada por tuda. Meu pai, Edsan Matsumata, minha mãe, Eliana F. Matsumata, ama racês!

A uida nunca nas faz esquecer das pessaas queridas que partem ceda, par issa dedica a vacê tamlém, meu querida prima Eduarda $S$. B. Duarte, que nãa sá deixau saudades mas também leaas lembranças, e que sempre estará em meu pensamenta.

A família é a base da sociedade e o lugar onde as pessoas aprendem pela primeira vez os valores que os guiarão durante toda a vida" 
A minha arientadara Maria Angélica Miglina pela apartunidade a mim cancedida, pela canfiança, arientaçãa e incentiva. Obrigada par cantriluir para meu crescimenta prafissianal e, especialmente pela respeita, atençãa, carinha e amizade. A vacê, minha eterna gratidãa.

As minhas queridas irmãs, Liliane S. Matsumata Juliana $\mathcal{E}$. Matsumata e Viviane S. Matsumata pela apaia, carinha e companhia, e par sempre me darem farça e incentiva para que eu pudesse passar par mais essa fase.

Aas meus grandes amigas: Claudia Tanashira, Jael Alues de Sausa, Renata Fantineli, Euander Buena, Guilherme Buzzan, e Ana Paula Castella, par tadas as mamentas de amizade, ajuda e companheirisma.

Amigas nas ensinam muita, nas fazem enxergar situaçães que às vezzes nãa perceleemas a seu real sentida, campartilham a suas experiência canasca, nas falam usanda da verdade que luscamas encantrar. Aa langa de nassa vida muitas amigas passam par ela e nas deixam saudades, mas também deixam a recardaçãa de tuda que fai uiuida. É na amizade verdadeira que encantramas a sinceridade, lealdade, afinidade, cumplicidade e simplicidade. 
a Tatiana Jazedje e a Tatiana Carlessa das Santas que contriluiam cam seus canhecimentas para elaharaçãa deste trabalha

Aa Carlas Eduarda Ambrásia e Daniele das Santas Martins pela ajuda desde a minha chegada em Sãa Paula e pela cantriluiçãa dada para elabaraçãa deste tralealha

à Faculdade de Medicina Veterinária e Zaatecnia da Uniwersidade de Sãa Paula, par praparcianar meu desenualuimenta científica, profissianal e pessaal.

A tadas as prafessares da Pragrama de Pás Graduaçãa da setar de Anatamia das Animais Damésticas e Siluestres

Aa Centra de estuda da Genama Humana pela par dispanibilizar a usa das labaratárias

A praf. Mariz Vainzof da Centra de Estuda da Genama Humana

Aas meus auás, Antania Hanária, Edelci M. Santas, Yalanda Matsumata, e a tadas meus tias e primas pela amar e carinha.

Aas meus primas Marcela Matsumata, Thais Matsumata e Renata Matsumata pela campanhia, ajuda e pelas caranas

Aas meus amigas de pás-graduaçãa, Ana Paula Silua, Victor Huga Radrigues, Siluia Pires Games, Fernanda Ladd, Fernanda Garbelatti, Thiaga Alaia, Elizangela das Anjas, Jasy Cal, Daniela Cagnata, Caue Pracápia, Amanda Vazzaler, Linda Tamaya, Jasé Eduarda Marques, Patricia Reginata, áluara Reweras, Flawia Rileira, Jaãa Marini e André Francialli.

A tadas as calegas de pás-graduaçãa pela traca de experiência e canuivência Cas meus amigas Thais M. Gançalues, Juliana C.de Sawza, Caralina Machada, Daniela Scaloppe, Patricia Biasi

A Janaína Manteira, Lilian Rangel, Priscila Watanabe e Adriana Marini p, Marina Osti e Carlas Francisca da Silua pela ajuda. 
a Mariana Secca, Eder Zuccani e Natashia Vieira pela ajuda na parte pratica deste trabalha

Aas técnicas da setar de anatamia pela amizade, carinha e ajuda: Sandra Affansa Freileerger, Ranalda Agastinha da Silua, Ednalda Rilas Farias (India), Diaga Mader, Jaãa da Carma Freitas, Raimunda Leal de Sausa e Natalia Garcia de Andrade (Branca)

As meninas da libliateca, Elza Maria R. B. Faquim, Fernanda Cezar Rileira e Helena Aparecida Tanganini, Maria Claudia Pestana pela calabaraçãa, dis panililidade e paciência

A Claudia Lima, Deise Maria Alues Flexa e Jaana Ferreira Dias Vascancelas, da secretaria de pás-graduaçãa

Aas Frigarificas Friganassa de Paças de Caldas e Mantiqueira de Sãa Jase das Campas pelas caletas cancedidas, e a tadas seus funcianárias pela ajuda nas caletas

A Fapesp-Fundaçãa de Ampara a Pesquisa de Sãa Paula pela apaia financeira e incentiua à pesquisa na estada de Sãa $\mathcal{T a u l a . ~}$ 


\section{RESUMO}

MATSUMOTO, F. S. Caracterização das proteínas do saco vitelínico de embriões bovinos Bos indicus. [Characterization of the yolk sac proteins of the Bos indicus bovine embryos]. 2007. $91 \mathrm{f}$. Dissertação (Mestrado em Ciências) - Faculdade de Medicina Veterinária e Zootecnia, Universidade de São Paulo, São Paulo, 2007.

O saco vitelínico é uma das membranas embrionárias que desempenham um papel importante para a sobrevivência inicial do embrião em muitas espécies de mamíferos, além de produzir proteínas necessárias para o desenvolvimento do mesmo. Foram coletados 17 embriões bovinos, em diferentes períodos gestacionais afim de identificar as proteínas alfafetoproteína, alfa- 1 antitripsina e transferrina, presentes no saco vitelínico destes,para tanto realizou-se a técnica de Western Blot com eletroforese em gel de poliacrilamida, SDS-PAGE a $6 \%$. Os géis, após a corrida, foram corados com Comassie blue, e as membranas de nitrocelulose, após a transferência, com Ponceau. Utilizaram-se os anticorpos monoclonal para alfafetoproteína anti-camundongo, monoclonal, receptpr de transferrin anti-camundongo $\lg G 1$, e policlonal para alfa- 1 antitripsina anti-coelho como anticorpos primário e conjugado para peroxidase e fosfatase como secundários. A revelação foi do tipo colorimétrica-fosfatase alcalina e por ECL. O saco vitelínico apresentou-se bem desenvolvido até os 50 dias de gestação, onde, a partir desse período o processo de involução está bem caracterizado Em algumas amostras do saco vitelínico detectamos a presença da alfafetoproteina, alfa-1 antitripsina e da transferrina, porém em algumas amostras as bandas estavam fracas, mostrando assim, que os anticorpos reagem com as proteínas bovinas. $O$ fato de aparecerem bandas fracas pode estar relacionado a uma fraca reação cruzada por se tratar de um anticorpo não específico.

Palavra-chave: Saco Vitelínico. Western Blot. Proteínas. Alfafetoproteina. Alfa-1 antitripsina. Transferrina. 


\begin{abstract}
MATSUMOTO, F. S. Characterization of the yolk sac proteins of the Bos indicus bovine embryos. [Caracterização das proteínas do saco vitelínico de embriões bovinos Bos indicus]. 2007. 91 f. Dissertação (Mestrado em Ciências) - Faculdade de Medicina Veterinária e Zootecnia, Universidade de São Paulo, São Paulo, 2007.
\end{abstract}

In many species of mammals, the yolk sac is one of the embrionary membranes that plays an important role in the embryo's initial survival, as well as, in the manufacturing of the necessary proteins for its development. In order to identify the proteins: alfafetoprotein, alfa 1 - antitrypsin, and transferrin present in the cow's embryo's yolk sac, 17 bovine embryos were collected in different pregnancy periods. This procedure was performed by Western Blot Technique with a polyacrylamide gel electrophoresis, SDS-PAGE, at $6 \%$. Gels following the electrophoresis, where tainted with Comassie blue, and the membranes of Nitrocellulose, following their transference (the proteins that were present in the gel go to the membrane), with Ponceau. Monoclonal Antibody mouse anti human $\alpha$-fetoprotein, alphafetoprotein mouse monoclonal antibody, transferrin receptor mouse $\lg G 1$, and rabbit polyclonal to alpha 1 antitrypsin were used as primary antibodies, and Peroxidase labelled antimouse e Peroxidase labelled antirabbit e anti-mouse IgG- Alkaline Fosfatase as secundary ones. The membrane's revelation was of the alcaline fosfatase colormetric type and by ECL. The yolk sac was presented well developed until the 50 days of gestation, where to break of this period the involution process well it is characterized. In some of the yolk sac samples we detected the presence of alfafetoprotein, alfa 1- antitrypsin, and transferrin, however, the bands in some specimens (samples) were weak, demonstrating that the antibodies react with the bovine proteins. The fact that weak bands appeared might be related to a weak cross reaction since we are dealing with a non specific antibody.

Key-words: Yolk sac. Western Blot. Proteins. Alfafetoprotein. Alfa 1- antitrypsin. Transferrin. 


\section{LISTA DE FIGURAS}

Figura 1 - Embriões bovinos e suas membranas fetais. Em A embrião com $0,87 \mathrm{~cm}$ de CR (15 a 20 dias) em B embrião com 1,3 cm de CR (20 a 30 dias). Em C embrião com 1,75 cm de CR e em $D$ embrião com 3,62 cm de CR (50.a 60 dias). Em A-D, embrião $(E)$, alantóide $(A L)$, âmnio $(A n)$ e saco vitelínico (Sv). Equivalente a $1 \mathrm{~cm}$

Figura 2 - Embriões bovinos e suas membranas fetais. Em A embrião com $1,75 \mathrm{~cm}$ de $\mathrm{CR}$ e em $\mathrm{B}$ embrião com $3,62 \mathrm{~cm}$ de $\mathrm{CR}$ (50.a 60 dias). Em $A$ e $B$, embrião $(E)$, alantóide ( $A L)$, âmnio (An) e saco vitelínico (Sv). Equivalente a1 cm

Figura 3 - A-D-Embriões bovinos $(E)$ em diferentes períodos gestacionais. Em A embrião com 0,60 cm (10 a 20 dias), mostrando o alantóide (Al), e parte e parte central (c) e extremidade (e) do saco vitelínico. Em B embrião com 1,25 com de CR (20 a 30dias) onde observamos o saco vitelínico (setas) e âmnio (am). Em C embrião com 1,75 com de CR (30 a 40 dias)ainda com a presença do saco vitelínico, parte central (c) e extremidades (e). Em D embrião com 2,77 (40 a 50 dias), mostrando o saco vitelínico bastante reduzido (Sv) e o cordão umbilical (seta)

Figura 4 - A1 e A2 Géis de poliacrilamida (SDS-PAGE) 6\% corado com Comassie Blue, mostrando apenas o peso molecular (PM) Biotinylated SDS Molecular Weight Standard Mixture Wide $(6,500-180,000)$

Figura 5 - Em A, gel SDS-PAGE 6\% corado com Comassie Blue, mostrando o peso molecular (PM) e em 2 e 3 amostras do saco vitelínico de embriões bovinos no período gestacional estimado de 30 a 40 dias. Em B membrana de nitrocelulose corada com Ponceau

Figura 6 - Membrana após a revelação do tipo ECL, mostrando o peso molecular (PM) e as amostras do saco vitelínico dos embriões 2 e 3 no período gestacional estimado de 30 a 40 dias de gestação, as setas vermelhas indicam a $\alpha$-fetoproteina com peso molecular de 70KDa

Figura 7 - Membrana de nitrocelulose corada com ponceau, mostrando o peso molecular Kaleidoskope (PM) e as amostras do saco vitelínico de embriões bovinos (1 a 3), em 1 e 4 embriões com período gestacional estimando de 0 a 15 dias, 2 e 3 com 50 a 60 dias de gestação 
Figura 8 - Membrana de nitrocelulose corada com ponceau, mostrando o peso molecular Kaleidoskope (PM), fígado fetal como controle positivo (1) e as amostras do saco vitelínico de embriões bovinos (2 a 9). Amostra 2 e 5 embriões com período gestacional estimado de 0 a 15 dias, amostras 3 e 4 de 50 a60 dias, amostras 6 a 9 de 30 a 40 dias e amostra 5 de 20 a 30 dias de gestação

Figura 9 - Membrana de nitrocelulose corada com ponceau, mostrando o peso molecular Kaleidoskope (PM) e amostras do saco vitelínico de embriões bovinos (1 a 4). Amostra 1, 3 e 4 embrião com período gestacional estimado de 30 a 40 dias, amostras 2 de 50 a 60 dias de gestação

Figura 10 - Membrana de nitrocelulose corada com ponceau, mostrando

o peso molecular Kaleidoskope (PM) e amostras do saco vitelínico de embriões bovinos (1 a 10). Amostra 1e 4 embrião com período gestacional estimado de 0 a 15 dias, amostras 2 , 6 e 7 de 30 a 40, amostras 3 e 9 de 50 a 60 dias, amostra 5 de 20 a 30 dias e amostra 8 de 40 a 50 dias de gestação

Figura 11 - Filme após revelação do tipo ECL, mostrando o peso molecular (PM), e as amostras do saco vitelínico de embriões bovinos (1 a 10). Mostrando as amostras do saco vitelínico de embriões bovinos (1 a 10) Amostra 1 e 4 embriões com período estimado de 0 a 15 dias, amostras 2, 6 e 7 de 30 a 40, amostras 3 e 9 de 50 a 60 dias, amostra 5 de 20 a 30 dias e amostra 8 de 40 a 50 dias de gestação, as setas indicam a proteína transferrina de $85 \mathrm{KDa}$

Figura 12 - A gel SDS-PAGE 6\% corado com Comassie Blue, mostrando o peso molecular (PM) e as amostras do saco vitelínico de embriões bovinos ( 1 a 6 ) Amostra 1 embriões com período estimado de 40 a 50 dias, amostras 2 de 40 a 50 dias de gestação amostras 3 e 4 de 30 a 40 dias, e amostras 5 e 6 de 0 a 15 dias e amostra 6 fígado fetal.

Figura 13 - Membrana de nitrocelulose corada com ponceau, mostrando o peso molecular Kaleidoskope (PM) e as amostras do saco vitelínico de embriões bovinos (1 a 3). Mostrando em 1 amostra de embrião com período estimado de 30 a 40 dias, 2 e 4 com 50 a 60 dias e 3 de 40 a 50 dias de gestação

Figura 14 - Membrana de nitrocelulose corada com ponceau, mostrando o peso molecular Kaleidoskope (PM) e as amostras do saco vitelínico de embriões bovinos (1 a 3), Em 1 embrião com período estimado de 30 a 40 dias, 2 com 40 a 50 dias e 3 de 50 a 60 dias de gestação 
Figura 15 - Membrana de nitrocelulose corada com ponceau, mostrando o peso molecular Kaleidoskope (PM) e as amostras do saco vitelínico de embriões bovinos ( 3 a 9), Em 1 amostra do fígado fetal, em 2, 3 e 8 embriões com período estimado de 30 a 40 dias, amostras 4 e 7 com 5 a 10 dias, amostras 5 a 650 a 60 dias, amostra 9 de 20 a 30 dias de gestação

Figura 16 - Membrana de nitrocelulose corada com ponceau, mostrando o peso molecular Kaleidoskope (PM) e as amostras do saco vitelínico de embriões bovinos (2 a 6), Em 2, 3 e 4 embriões com período estimado de 30 a 40 dias, amostras 5 com 40 a 50 dias, amostras 6 de 50 a 60 dias de gestação

Figura 17 Filme após a revelação do tipo ECL mostrando o peso molecular Kaleidoskope (PM) e as amostras do saco vitelínico de embriões bovinos (1 a 9), Em 1 amostra do fígado fetal, em 2 , 3 e 8 embriões com período estimado de 30 a 40 dias, amostras 4 e 7 de 5 a 10 dias, amostras 5 e 6 de 50 a 60 dias amostra 9 de 20 a 30 dias de gestação. As setas vermelhas indicam a proteína alfa- 1 antitripsina

Figura 18- Filme após a revelação do tipo ECL mostrando o peso molecular Kaleidoskope (PM) e as amostras do saco vitelínico de embriões bovinos (1 a 5). Em 1, 2 e 3 embriões com período estimado de 30 a 40 dias, 4 amostras de 40 a 50 dias e 5 de 50 a 60 dias de gestação. As setas vermelhas indicam a proteína alfa- 1 antitripsina.

Figura 19- Filme após a revelação do tipo ECL mostrando o peso molecular Kaleidoskope (PM) e as amostras do saco vitelínico de embriões bovinos ( 3 a 9), Em 1 amostra do fígado fetal, em 2, 3 e 8 embriões com período estimado de 30 a 40 dias, amostra 4 e 7 de 5 a 10 dias, amostra 5 e 6 de 50 a 60 dias, amostra 9 de 20 a 30 dias gestação. As setas vermelhas podem estar indicando uma reação inespecífica

Figura 20 Filme após a revelação do tipo ECL mostrando o peso molecular Kaleidoskope (PM) e as amostras do saco vitelínico de embriões bovinos (1 a 5), Em 1, 2 e embriões com período estimado de 30 a 40 dias, 4 com 40 a 50 dias e 5 de 50 a 60 dias gestação 


\section{LISTA DE TABELA}

Tabela 1 Período gestacional estimado segundo o Crow-rump dos embriões....

Tabela 2 Receita dos protocolos utilizados na preparação dos géis de poliacrilamida.

Tabela 3 Resultado obtido e o período em que os diferentes protocolos para o preparo do gel de poliacrilamida foram preparados.

Tabela 4 Relação entre os anticorpos utilizados,seu isotipo, hospedeiro, marca e diluições utilizadas

Tabela 5 Relação entre o período gestacional estimado e o tamanho dos embriões coletados.

Tabela 6 Medidas das absorbâncias a 595 das diferentes concentrações de BSA.

Tabela 7 Concentrações protéica das diferentes amostras de saco vitelínico de embrião bovino e suas absorbância a $595 \mathrm{~nm}$. 


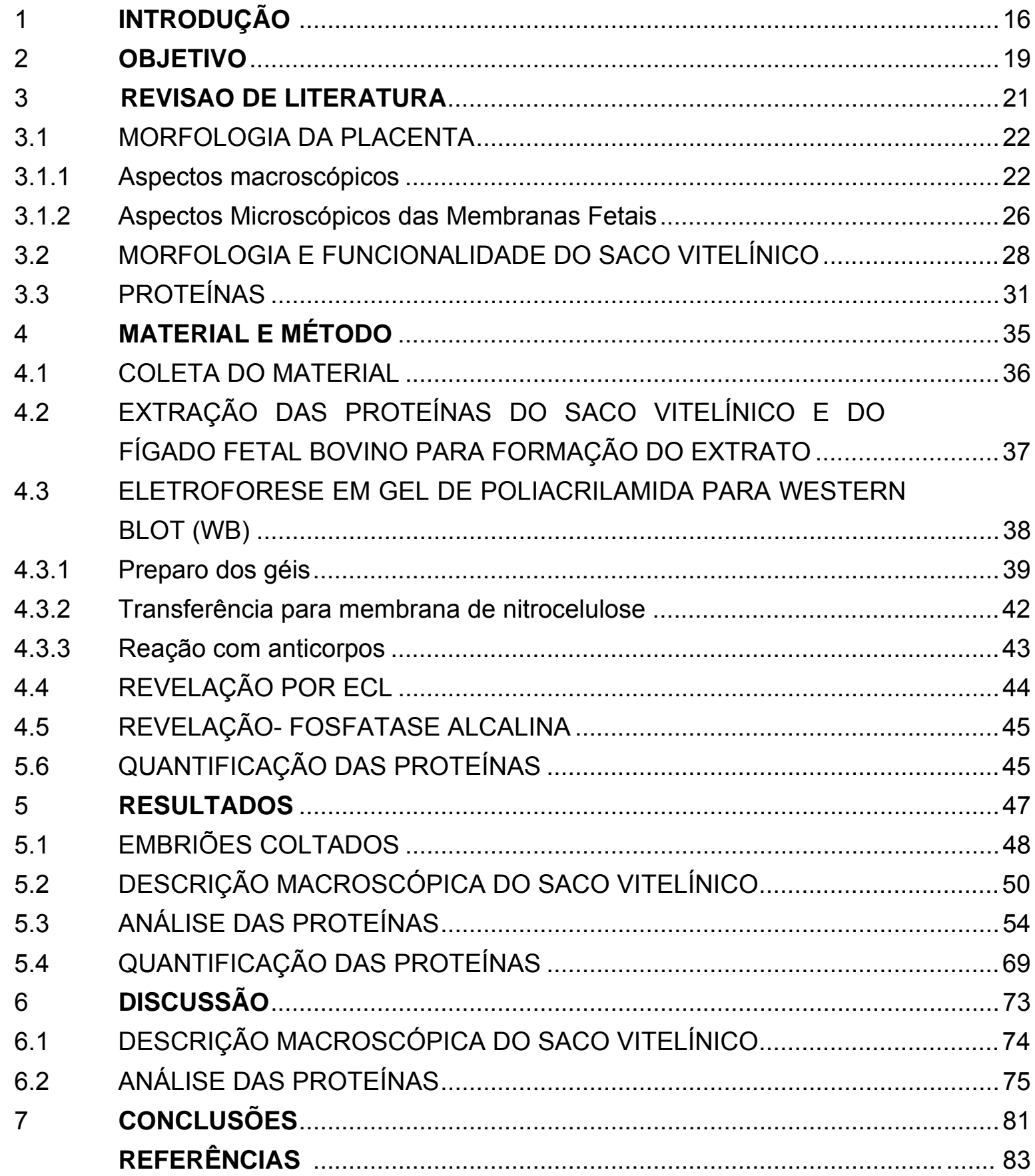


INTTRODUÇÃO 


\section{INTRODUÇÃO}

Devido a sua morfologia, suas peculiaridades fisiológicas e por sua própria ecologia, as raças indianas (Bos indicus) são consideradas como pertencentes a uma espécie diferente do boi europeu (Bos taurus). Esta raça constitui a maior população bovina mundial, havendo, somente na Índia, cerca de duzentos milhões de indivíduos. A sua expansão é constante em todos os países tropicais. No momento atual, o zebu é uma constante em qualquer referência a assuntos de pecuária tropical, desde que já se acham mundialmente aceitas as qualidades da raça capaz de produzir economicamente no referido ambiente (BEZERRA, 2000).

Hoje em dia, as técnicas de transferência e produção in vitro de embriões bovinos estão crescendo e se aprimorando cada vez mais. Mas muitas vezes, o meio de cultivo utilizado na produção in vitro afeta o desenvolvimento após a fecundação e interfere no metabolismo ou na expressão de genes importantes para o desenvolvimento do embrião (ALVES et al. 2003).

As membranas extra-embrionárias (alantóide, âmnio, cório e saco vitelínico), são responsáveis pela comunicação materno-fetal e pela formação, posteriormente, da placenta (WOLF et al. 2003). O saco vitelínico é uma das membranas que desempenham um papel importante para a sobrevivência inicial do embrião em muitas espécies de mamíferos, além de produzir proteínas necessárias para o desenvolvimento do mesmo.

As proteínas são polímeros que desempenham inúmeras funções biológicas e também determinam a forma e a estrutura das células, dentre algumas funções, as proteínas catalizam um enorme número de reações químicas, controlam a permeabilidade das membranas, regulam a concentração de metabólitos, e controlam a função genética (ZAHA; FERREIRA; PASSAGLIA, 2003). As proteínas especializadas também podem atuar como anticorpos, toxinas hormônios, moléculas anticongelantes e fibras elásticas (ALBERTS et al. 2006).

Os princípios da eletroforese estão baseados nos conhecimentos da composição química das proteínas e nos fatores, carga elétrica e peso molecular, 
os quais determinam sua migração eletroforética (MELVIN 1987; NAOUM 1990) Esta técnica tem sido utilizada como método de referência para o fracionamento e quantificação das proteínas séricas em bioquímica clínica (EVENSON 1982; KANEKO, 1989)

A eletroforese em gel é um dos métodos mais utilizados para analisar misturas de proteínas ou outras macromoléculas. Existem dois modelos básicos de eletroforese, os baseados em géis de agarose e os em géis de poliacrilamida. Esses géis propiciam separação das moléculas segundo seu tamanho, além da sua carga (MARZZOCO; TORRES, 2001)

$\mathrm{Na}$ década de 70 foi descrita a eletroforese em gel de agarose, a qual possibilita a detecção de várias frações, sendo chamada de técnica eletroforética de alta resolução (JONHANSSON, 1972), uma vez que o gel de agarose permite a separação de proteínas com mobilidade similar (VOSS, 1987). Os géis de poliacrilamida são meios de suporte preferidos para a eletroforese porque são quimicamente inertes e são prontamente formados. Este gel forma uma malha constituída por uma rede de polímeros que permite a migração de moléculas de acordo com seu peso molecular (BERG; TYMOCZKO; STRYER, 2004).

São poucos os trabalhos realizados sobre o reconhecimento antigênico por anticorpos de proteínas relevantes em saco vitelino de bovinos. Este fato, provavelmente, está relacionado à dificuldade em se obter material em quantidade protéica suficiente e para a caracterização das mesmas, na espécie em questão.

A importância do estudo do perfil proteico do saco vitelínico de embriões bovinos deve-se também ao maior conhecimento sobre os componentes que garantem a manutenção do desenvolvimento embrionário e fetal. Para o crescimento embrionário e fetal são necessários elementos inorgânicos e orgânicos (KJELDSBERG; KNIGHT, 1993).

Com isso, a análise proteica do fluído fetal favorece um melhor conhecimento e compreensão de todo o processo bioquímico que está envolvido no desenvolvimento do embrião e do feto. 


\section{OBJETIVOS}

Caracterizar o perfil protéico do conteúdo do saco vitelínico de embriões bovinos com até 40 dias de gestação, através de eletroforese em gel de poliacrilamida seguida da técnica de Western blot (WB).

Serão identificadas as seguintes proteínas:

1-) Transferrina;

2-) Fetoproteína;

3-) $\alpha_{1} 1$-antitripsina. 
REVISÃO DE LITERATURA 


\section{REVISÃO DA LITERATURA}

A revisão de literatura foi dividida nos seguintes tópicos: Morfologia da placenta, morfologia e funcionalidade do saco vitelínico e proteínas.

\subsection{MORFOLOGIA DA PLACENTA}

Para descrição da morfologia da placenta separamos em aspectos macro e microscópico

\subsubsection{Aspectos Macroscópicos}

As membranas fetais, cório, alantóide, âmnio e o saco vitelínico, representavam as estruturas membranosas do embrião intimamente envolvidas na morfogênese da placenta (BOWEN; BURGHARDT, 2000). Estas membranas podiam estabelecer conexões entre si ao longo de todo o desenvolvimento placentário, sendo que estas conexões podiam ser transitórias, se tornarem permanentes ou ainda comportar-se de forma diferente de acordo com a espécie (ASSIS NETO, 2005).

A placenta representava uma aposição ou fusão de tecidos, que tinha a função de realizar trocas de nutrientes e excreção de resíduos, entre as regiões materna e fetal. A eficiência morfológica da membrana fetal estava relacionada à grande área superficial de aposição das camadas, e os sangues materno e fetal, embora próximos um do outro, continuavam morfologicamente separados por uma variedade de camadas celulares da membrana fetal (BJÖRKMAN, 1973).

De acordo com Leiser e Kaufmann (1994) existiam quatro modelos para a classificação da placenta em relação à composição das membranas fetais: 
placenta coriônica, placenta coriovitelínica, placenta cório-alantóide e placenta vitelínica.

A placenta coriônica, na espécie humana, estava presente no final da gestação como uma porção não vascularizada e não especializada, e era o primeiro passo do desenvolvimento placentário em todos os mamíferos. $\mathrm{Na}$ placenta coriovitelínicas da égua e da gata, as membranas coriônicas estavam conectadas à circulação fetal por vasos vitelínicos. A placenta cório-alantóide estava presente na maioria dos mamíferos domésticos,e apresentava a membrana coriônica conectada à circulação fetal pelos vasos alantóides. Na placenta vitelínica, presentes em roedores, o epitélio do saco vitelínico e os vasos vitelinícos apresentavam-se conectados à circulação fetal (LEISER; KAUFMANN, 1994).

Garcia e Fernandez (2001) descreveram a placenta como sendo um órgão de tecidos tanto fetais quanto maternos que servia de transporte de nutrientes e oxigênio da circulação materna para o feto e de resíduos metabólicos e $\mathrm{CO}_{2}$ da circulação fetal para a materna. Sendo assim, considerado um órgãoelo entre a mãe e o filho, que permitia uma analogia ao ovo mais simples oligolécito, pois proporcionava ao indivíduo em desenvolvimento a garantia de suas necessidades básica: respiração, nutrição e eliminação de seus catabólitos.

King (1982) relatou que as placentas da maioria dos mamíferos tinham modificações que ampliavam a quantidade de superfícies da área disponível à absorção de nutrientes. Essa ampliação poderia estar na espessura histológica ou num nível ultra-estrutural de organização, já que a área de superfície disponível para transporte era importante parâmetro para determinação da taxa na qual muitos poderiam ser transferidos para o feto.

Hafez e Hafez (2004) concluíram que a placenta desempenhava muitas funções e substituía o trato gastrointestinal do feto, os pulmões, os rins, o fígado e as glândulas endócrinas. A placenta permitia o transporte de açucares, aminoácidos, vitaminas e sais minerais para o feto como substrato para seu crescimento. Sua morfologia durante a gestação inicial estava intimamente relacionada às membranas fetais ou extra-embrionárias que estavam 
diferenciadas em âmnio, alantóide, cório e saco vitelínico. Estas estruturas participavam da formação da placenta, separadamente ou em certas combinações e davam origem a três tipos de placentação, que diferiram em relação à identidade das membranas fetais envolvidas: placentação coriônica, corioalantóide e saco vitelino. Dentre estes tipos, a placentação corioalantóide era característica de todos os animais domésticos. De acordo com esses autores, a placentas foram classificadas de acordo com a morfologia, com as características microscópicas da barreira materno-fetal e com a perda de tecido materno por ocasião do parto. Sua forma era determinada pela distribuição das vilosidades sobre a superfície coriônica. Em ruminantes, os cotilédones fetais se fundiram com as carúnculas ou projeções especializadas da mucosa uterina, formando os placentomas ou unidades funcionais.

Arthur (1979) e Salesbury e Vandermark (1964) afirmaram que a placenta podia ser classificada de acordo com a maneira de distribuição dos processos vasculares no cório fetal, existindo assim, nas espécies domésticas tipos generalizados de placenta, onde estes se encontravam grupados em múltiplas áreas fixas, como nos ruminantes, a disposição era denominada disposição placentária cotiledonária, sendo a placenta classificada como cotiledonária, onde as vilosidades estavam localizadas em uma centena de rosetas. Onde eles estavam uniformemente dispersos, como na égua e porca, esta era dita como sendo difusa, onde todo o cório estava coberto por vilosidades de aspecto digital.

Drieux e Thiery (1951) descreveram que na vaca os cotilédones estavam em número de 120 a 140 e possuíam forma ovóide. Estes apresentavam um enorme tufo de vilos oriundos do cório fetal que se engrenavam no receptáculo materno. Esta topografia placentária e secundária ocorreu após a formação de uma placenta difusa primária de existência efêmera.

A implantação em mamíferos era resultante de uma série de interações altamente coordenadas que começavam com o contato íntimo entre a superfície das membranas do concepto e o epitélio uterino e terminavam com a formação de um órgão complexo, a placenta, com funções de proteção, nutrição e respiração (BOWEN; BURGHARDT, 2000). 
Junqueira e Carneiro (1990) relataram que a implantação ou nidação ocorria quando o endométrio estava na fase secretora. Durante esse processo o trofoblasto se diferencia em duas camadas: o sincíciotrofoblasto, mais externo e possuía núcleos volumosos e seu citoplasma é contínuo, formando um sincício e o citotrofoblasto, constituído por uma camada irregular de células ovóides. Após a implantação do embrião o endométrio modificava-se e passava a ser chamado de decídua. Distinguindo-se a decídua basal ou serotina, situada entre o embrião e o miométrio; a decídua capsular ou reflexa, entre o embrião e a luz do útero; e a decídua parietal, ou vera, que era o restante da decídua.

De acordo com Filho (1987) nos animais deciduados, a placentação se fez simultaneamente a nidação, pois muito cedo o embrião aderia ao útero e nele se aprofundava. Da coroa de células auxiliares se diferenciava o cório, membrana ovular mais externa e que entrava em contato direto com o útero, constituindo o trofoblasto. Do próprio cório, por invaginação formava o âmnio, considerado como continuação da pele, formando um saco que englobava o embrião. Dos intestinos primitivos derivavam duas formações, que ocupavam quase toda a parte inferior do embrião, formava-se o saco vitelínico, na parte inferior do intestino primitivo e o alantóide. O cório representava o elemento de contato com a parede materna e cedo diferenciava-se, apresentando expansões apropriadas para atacar e digerir as substâncias colocadas em seu alcance. O âmnio representava um envoltório que recobria o embrião, cheio de líquido amniótico, alcalino, rico em albumina, uréia, sais minerais e açúcar. O saco vitelino não apresentava uma função específica importante na fisiologia do embrião. Nos mamíferos durante a evolução embrionária, o saco vitelino regredia.

Leiser e Kaufmann (1994) estudaram comparativamente aspectos estruturais em placenta de alguns mamíferos tais como, eqüino, suínos, ruminantes domésticos, gato, cobaia e do homem, e propuseram termos para uma classificação de acordo com: o tipo das membranas placentárias, a interdigitação materno-fetal, as camadas da barreira placentária, a invasão trofoblástica, a reação das células teciduais, a formação do sinciotrofoblasto, as interrelações de fluxo sanguíneo materno fetal e a separação da placenta ao nascimento. Estes 
termos originaram-se parcialmente da classificação básica das placentas, e foram obtidas dos resultados das pesquisas recentes, que auxiliava no melhor entendimento da estrutura e da função dos diferentes tipos placentários.

Segundo Liu et al. (1991) em ruminantes domésticos, acreditava-se que as proteínas secretadas e produzidas pelas membranas fetais mediavam algumas interações materno-fetal, e que eram essenciais para o estabelecimento e a manutenção da gestação. Enquanto a gestação avança, a produção de proteínas pelas membranas, tornava-se mais complexa. Essas mudanças ocorriam aproximadamente nos 24-29 de gestação nas vacas e 21-23 dias de gestação nos carneiros e nas cabras, e coincidiram com o desenvolvimento do alantóide e sua fusão com o cório.

\subsubsection{Aspectos Microscópicos das Membranas Fetais}

Do ponto de vista microscópico, a placenta podia ser: hemocorial, endoteliocorial, sindesmocorial e epiteliocorial, sendo assim denominadas em função da barreira placentária (que separa o sangue materno do embrionário ou fetal). Na sindesmocorial estavam presentes os endotélios vasculares embrionário ou fetais, conjuntivos da vilosidade, trofoblasto, endotélio vascular materno e conjuntivo endometrial, onde o epitélio uterino persistia parcialmente, sendo encontrada nos ruminantes (ALMEIDA, 1999).

De acordo com Bacha e Bacha (2003), a placenta derivava do endométrio e da membrana cório-alantóica (MCA). O grau de intimidade entre esses dois compartimentos variava e era a base para a classificação de placentas. Uma placenta era classificada como indecídua quando essas duas membranas estavam em contato, mas não estavam intimamente fundidas, e decídua, quando as membranas se fundiam. Em animais que possuíam placenta indecídua (éguas, ruminantes e porcas) perdeu-se pouco ou nenhum endométrio durante o processo de nascimento, contrariamente perdeu-se uma quantidade considerável de mucosa no parto em animais com placenta decídua (carnívoros). A extensão em 
que a MCA contribuía para a placenta era variável, se a maior parte de MCA contribuiu (tal como éguas e porcas) a placenta será difusa; se áreas numerosas, porém isoladas, contribuírem (tal como em ruminantes), a placenta era cotiledonar; quando uma porção semelhante a um cinto de MCA contribui (tal como em carnívoros), a placenta era zona.

A classificação de placentas também podia ser baseada no número de camadas teciduais que separavam o sangue fetal e materno. Em éguas e porcas, interviam seis camadas: endotélio, tecido conjuntivo e epitélio da MCA; epitélio, tecido conjuntivo e endotélio do endométrio. Essa configuração caracterizava a placenta epitéliocorial. Em ovelhas e cabras, perdia-se o epitélio das carúnculas, e com isso, reduzia o número de camadas teciduais a cinco (placenta sindesmocorial), já em vacas o epitélio das carúnculas permanecia intacto (epitéliocorial), mas porções do epitélio intercaruncular se degeneravam. Em carnívoros perderam-se tanto o epitélio endometrial como o tecido conjuntivo endometrial, fazendo com que o epitélio da MCA e o endotélio endometrial entrassem em contato. Nesse tipo de placenta somente quatro camadas separavam o sangue fetal e o materno (BACHA; BACHA, 2003).

Segundo Costa (1957) e Almeida (1999) a placenta podia ser classificada como: Placentas Veras ou Deciduadas (epitélio corial ou zonária e hemo-corial ou discóide), Semiplacentais ou indeciduadas (epitélio corial ou difusa) e sindesmocorial múltipla ou cotiledonar, onde apresentavam vilosidades coriais que se condensavam em pequenas massas denominadas cotilédones, onde o epitélio uterino destruía-se de forma que o epitélio corial ficava em contato com o tecido conjuntivo materno. Essa destruição permitiu considerar que esse tipo de placentação em mamíferos era observada como forma de transição entre indeciduados e deciduados. Pertencentes a esse grupo estava os ruminantes. 


\subsection{MORFOLOGIA E FUNCIONALIDADE DO SACO VITELINO}

O saco vitelínico foi a primeira das membranas fetais a desenvolver-se em marsupiais e eutérios, mas nesses últimos era posteriormente substituído pela placenta cório-alantóide, a qual era característica da maioria dos mamíferos.

A importância do saco vitelínico como órgão placentário hematopoiético foi bem conhecida nos roedores, mas o mesmo não acontece nos mamíferos domésticos, onde as informações eram bastante escassas (MOSSMAN, 1987).

Salesbury e Vandermark (1964) afirmaram que o embrião muito jovem podia existir durante breve tempo graças aos nutrientes que absorvia do seu próprio saco vitelino e do leite uterino. A medida que aumentava de tamanho era necessário um estabelecimento de um melhor sistema de nutrição. As três camadas embrionárias derivaram não somente de diversos tecidos do próprio embrião em crescimento, mas também das membranas que o envolvia, protegia e permitia, por último, obter alimento necessário. Os vasos sanguíneos que se formavam na parede do saco vitelino se encarregavam de transportar para o embrião os materiais do leite uterino. A atividade funcional do saco vitelínico durava muito pouco, pois seu papel era desempenhado pelo alantóide.

Segundo Costa (1957) o saco vitelino provinha do endoblasto que se diferenciava na fase profunda do botão embrionário e que continuando sua proliferação invadia a área extra-embrionária. Com relação a circulação vitelina, o conjunto de vasos que se formavam as custas dos ilhéus de Wolff na parede do saco vitelínico assegurava a chamada circulação vitelínica que ligava essa parede ao embrião. Os vasos eferentes do embrião eram formados por artérias vitelínicas, a princípio muito numerosas, e por ramos das aortas abdominais. Os vasos aferentes para o embrião formavam as veias vitelinas ou ônfalo-mesentéricas que continuavam-se com os dois tubos endocárdicos. Destes provinham as aortas, fechando assim o circuito.

A formação do saco vitelínico visceral foi um evento inicial crítico no desenvolvimento pós-implantação em mamíferos. Algumas funções vitais do saco 
vitelínico visceral para crescimento e diferenciação embrionária consistia na absorção e digestão de nutrientes maternal, síntese de proteínas, formação da circulação vitelínica e secreção intravascular de nutrientes (FARRINGTON, BELAOUSSOFF; BARON, 1997).

Kaufmann e Davidoff (1977) e Leiser e Kaufmann (1994) consideravam que as regiões nas quais o saco vitelino estava associado a um mesênquima vascularizado, em locais próximos a placenta principal, eram estruturas capazes de realizar eficientes funções de transportes e foram denominadas de placentas vitelinas ou região paraplacentária das membranas fetais.

O saco vitelino era um órgão placentário e hematopoiético, essa função foi bem conhecida nos roedores (KING; ENDERS, 1970), mas isso não aconteceu nos mamíferos domésticos onde as informações eram bastante escassas.

O saco vitelínico tinha um papel principal no desenvolvimento embrionário de todos os mamíferos. O saco vitelínico extra-embrionário era um dos locais iniciais da hematopoiese. Em roedores servia como a principal membrana materno-fetal para mudanças ao longo da gestação. Esta capacidade de sintetizar e secretar proteínas em compartimento embrionário e extra-embrionário foi freqüentemente usado como modelo para embriologia experimental e toxocologia reprodutiva (GULBIS et al., 1998).

Barone (1976) afirmou que o saco vitelino involue e se degenera muito cedo nos ruminantes, e a partir da segunda semana seus vestígios não eram encontrados até o final da prenhez.

Em ruminantes domésticos como gado, ovelha e cabra, proteínas produzidas pelas membranas extraembrionárias eram mediadoras de algumas interações materno-fetal necessárias para o estabelecimento e manutenção da gestação. O saco vitelínico dos bovinos alcançava o desenvolvimento ao redor do $20^{\circ}$ dia de gestação, e então sofria regressão rápida (GODKIN J. D., 1988).

O saco vitelino de mamíferos domésticos era incialmente grande, mas regredia quando a placenta permanente se desenvolvia. Embora esta era uma estrutura transitória, possuía várias funções importantes como nutrir a placenta 
permanente até que a mesma estivesse formada, sendo especialmente importante nos eqüinos e carnívoros. Alguns dos vasos sanguíneos vitelínicos dentro do embrião eram mantidos como principais vasos sanguíneos viscerais no adulto. Sua parte endodérmica dava origem às células germinativas primordiais (células sexuais primárias) que posteriormente migravam para as gônodas que também apresentavam características de células produtoras de hormônios esteróides (LATSHAW, 1987).

Inicialmente o saco vitelínico apresentava-se grande e vascular, sendo completamente envolvido pelo celoma, separado do cório e completamente vascularizado ao redor do $20^{\circ}$ dias de gestação na vaca, apresentava apenas uma existência transitória, pois era precocemente deslocado pelo rápido crescimento do saco alantóide (LATSHAW, 1987). As mesmas observações foram feitas por Bryden, (1965) e Noden e Lahunta (1972) onde observaram que em ruminantes este era grande e vascularizado e estava completamente solto do cório ao redor do $20^{\circ}$ dia de prenhez na vaca. Ao redor do $25^{\circ}$ dia de prenhez, ficava reduzido a uma estrutura sólida como um cordão. Em mamíferos domésticos era transitório, entretanto tinha grande importância em realizar trocas embrionárias e maternas antes que placenta permanente estivesse formada. Conforme a cavidade se expandia, a área de transferência efetiva da placenta vitelina diminuía, e quando a formação da cavidade extraembrionária estava completa a separação do mesoderma no ponto de fixação entre o saco vitelínico e o cório era destruída. Nesta hora uma placenta vitelina não mais existia.

De acordo com Meenhan et al. (1984), o saco vitelínico executava muitas funções do fígado no embrião em desenvolvimento, antes do amadurecimento do fígado fetal. Sendo assim, havia conseqüências importantes a respeito da regulação da expressão gênica protéica no tecido adulto e fetal.

De acordo com Rüsse et al. (1992) a circulação no saco vitelino em bovinos e ovinos era responsável pela transmissão de metabólicos entre a mãe e o feto por um longo período embrionário. 
O saco vitelínico podia executar as funções do fígado no desenvolvimento embrionário antes da maturação do fígado fetal, e que sintetizava ainda uma variedade de proteínas em comuns com o fígado fetal (GULBIS et al. 1998).

O saco vitelínico visceral formava uma interface entre os tecidos materno e fetal e contribuiu para manter o conteúdo protéico do compartimento extracelular fetal. Proteínas secretadas por essa membrana eram capazes de entrarem na circulação fetal. Embora secretasse proteínas protoplasmáticas, não se sabia ainda a direção desta secreção (THOMAS et al. 1990).

Segundo Liu et al. (1991) similar ao fígado fetal, o saco vitelínico e o alantóide tinham funções hematopoiéticas durante estágios específicos do desenvolvimento embrionário para que a produção do RBP possa servir para transportar o retinol necessário para a diferenciação e proliferação hematopoiética das células.

\subsection{PROTEÍNAS}

O saco vitelínico do camundongo produzia especificamente proteínas idênticas as proteínas do soro fetal de bovinos como a transferrina, $\propto_{1^{-}}$

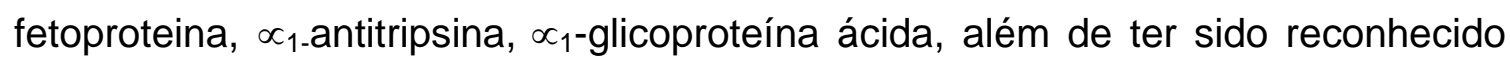
por muito tempo por ter tido a função hepática fetal tal como a hematopoiese e a produção de proteínas durante o início do desenvolvimento embrionário (LIU et al. 1991).

Em estudos realizados por Gitlin e Perricelli (1970), o saco vitelínico de coelhos produziu proteínas como: prealbumina, albumina, a transferrina, $\propto_{1}$

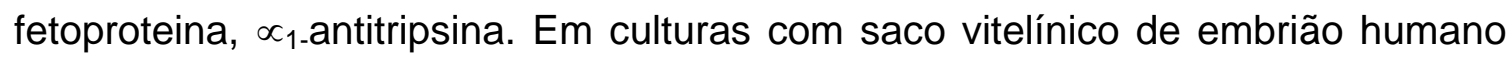
com 5-5 semanas de gestação demonstraram grandes quantidades das proteínas

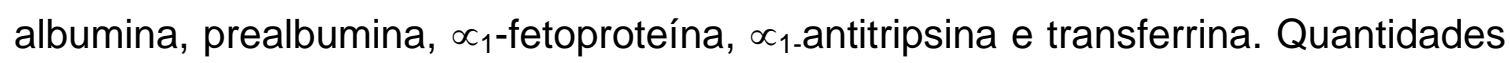
um pouco menores estavam presentes na cultura de saco vitelínico de embrião com 8-5 semanas de gestação e na cultura de embriões de 11-5 semanas 
encontrou-se prealbumina e antitripsina e uma pequena quantidade de albumina,

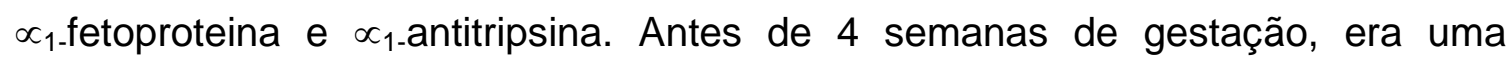
vesícula bem definida, e o fígado representado por brotos e ductos hepáticos que sintetizam, prealbumina, albumina, $\propto_{1}$-fetoproteína, $\propto_{1}$-antitripsina e transferrina, além de outras proteínas.

De acordo com Thomas et al. (1990) transtiretina, transferrina e $\propto_{1}$ fetoproteína foram detectadas no saco vitelínico visceral e no fígado fetal do camundongo, mas uma maior quantidade dessas proteínas foi produzida pelo saco vitelínico no início da gestação.

As proteínas produzidas pelo saco vitelínico de varias espécies de mamíferos possuíam uma grande importância no desenvolvimento embrionário e fetal.

Segundo Brock et al. (1976) a transferrina era uma proteína de peso molecular de $85 \mathrm{KDa}$ essencialmente sintetizada pelo fígado e estava envolvida no transporte de ferro e quando cultivada in vitro mostrou um efeito bacteriostático, e em experiências in vivo sugeriu que este mecanismo pode contribuir para defesas contra bactérias patogênicas, indicando assim uma outra possível função fisiológica dessa proteína. De acordo Streu et al. (2000) a transferrina, uma glicoproteina presente em altas concentrações no fluido amniótico, realizava o transporte de ferro durante a prenhez, suprindo o aumento da demanda fetal de ferro. Sugeriu ainda que essa glicoproteína tinha influencia no controle da produção de progesterona modulando a função endócrina dos trofoblastos. $E$ de acordo com Carlson (1994), a superfície placentária possuía receptores específicos para essa proteína. Aparentemente, o ferro se deslocava da transferrina na superfície placentária, sendo então ativamente transportado para os tecidos fetais.

A alfa-1-antitripsina (A1AT), uma glicoproteína de peso molecular de 52 KDa produzida principalmente pelos hepatócitos que liberavam diariamente cerca de $2 \mathrm{~g}$ da proteína na circulação. A principal função da A1AT era inibir a elastase neutrofílica, uma protease de serina que tem a capacidade de hidrolisar as fibras de elastina no pulmão, que inibia a ação de outras enzimas que quebram as 
proteínas. A deficiência de alfa1-antitripsina permitia que as demais enzimas lesavam os tecidos pulmonares (AIRES, 1999). Segundo Takashina et al. (2004) a A1AT era um inibidor de protease produzido por células epiteliais do âmnio no periodo gestacional e pelos hepatócitos ao longo de todoa a vida do individuo. Vatine et al. (1996) comprovou que a A1AT agia como inibidor das proteinas elastase e tripsina, porém em sítios de ligações diferentes. Observou também sua importancia em processos inflamatórios pulmonares, onde possuía a capacidade de inibir a migração de macrófagos alveolares.

A deficiência desta proteína era uma disfunção de causa ainda desconhecida que desencadeou manisfestações clínicas de diferentes graus, como cirrose hepática, doenças obstrutivas crônicas e enfisemas pulmonares, e até mesmo paniculites, que podia ser diagnosticadano período de gestação, em humanois, para avaliação do nível desta proteina (RICHMOND; ZELLNER, 2005).

A AFP (alfafetoproteína), uma glicoproteína embrionária com peso molecular de $70 \mathrm{KDa}$ era produzida no segundo mês de gestação pelo saco vitelínico visceral, pelo fígado fetal e pelo trato gastrointestinal (GULBIS et al. 1998). A AFP humana era a principal glicoproteína plasmática sintetizada durante o desenvolvimento pelos hepatócitos, saco vitelínico e em menor quantidade pelo fígado fetal. Durante a gestação, cruzava a via placenta ou fluido amniótico do feto para a mãe (HAU, et al. 1981).

A alfafetoproteína (AFP) uma glicoproteína de peso molecular de aproximadamente 69.000 daltons era sintetizada pelo saco gestacional (vesícula vitelínica), trato gastrointestinal e principalmente pelo fígado fetal mas em pequenas quantidades podiam ser produzidas pelos rins e placenta (MILUSNSKY, 1992 e DAFFOS e FORESTIER, 1988. De acordo com Zizkovsky (1975) a AFP era uma proteína sintetizada pelo saco vitelínico e fígado fetal da maioria dos mamíferos, com função ainda desconhecida. Em um estudo realizado por Alpert (1972) a AFP humana apresentou peso molecular de 72KDa.

A função biológica da alfafetoproteína no feto ainda permanecia desconhecida. Acreditava-se apenas em uma função imunológica envolvida na prevenção da rejeição do feto pela mãe (DAFFOS e FORESTIER 1988) 
Yachinin, Soltani e Lester (1980) concluiram que a AFP era imunosupressiva. Gorin et al., (1981) estudou que em fetos essa proteína podia ser comparável à albumina sérica de adultos. E Lowset et al. (1991) verificou que esta proteína atuava na proteção das células neurais dos altos níveis de estrógenos durante o desenvolvimento fetal. Observou ainda que seu nível apresentou valores significantemente aumentos no carcinoma hepatocelular e em tumor de células embrionárias humanas e animais, o que auxiliavam na realização do diagnóstico e monitoramento de resposta e terapias.

Segundo Gorin et al. (1981) a principal proteína para o desenvolvimento do feto era a AFP, que era sintetizada pelo fígado e saco vitelínico embrionário. Depois do nascimento suas concentrações diminuiam dràsticamente aos níveis que são mal detectáveis em adultos não-gestantes. A queda do nível dessa proteína resultava em uma diminuição gradual de sua taxa sintetizada pelo fígado e, no exemplo dos roedores, pela perda do saco vitelínico, entretanto sua síntese era recomeçada no fígado adulto durante a sua degeneração, e em tumores específicos tais como hepatomas e teratocarcinomas. Descreveu ainda que haviam similaridades estrutural e funcionais entre AFP e albumina, que levou à sugestão que servia como uma albumina fetal. As concentrações elevadas de AFP e de albumina no plasma ajudavam no controle do plasma e da pressão osmótica do líquido intravenoso. A AFP estava relacionada também a uma resposta imune da mãe e da proteção do feto, em roedores, dos efeitos de estrógenos maternal. 


\section{MATERIAL E MÉTODO}

O material e método utilizados foram descritos abaixo. Estes referem-se a coleta do material a descrição da técnica de Western Blot, e a quantificação das proteínas.

\subsection{COLETA DO MATERIAL}

Foram coletados 17 embriões provenientes de abatedouros/frigoríficos da região de Dracena-SP, da região de São José dos Campos-SP e da região de Poços de Caldas-MG.

Após evisceração dos animais, na linha de abate, os úteros foram identificados, incisados, e o embrião bem como suas membranas fetais foram retirados e acondicionados em potes plásticos e conservados no isopor com gelo até chegarem ao laboratório do Centro de Estudo do Genoma Humano-USP, São Paulo. O saco vitelínico foi caracterizado macroscopicamente, retirado do embrião e congelado a $-20^{\circ} \mathrm{C}$ ou colocado em solução fisiológica até o momento da extração das proteínas. O fígado também foi retirado do embrião, e fragmentos de 0,5 cm foram cortados e colocados em tubos cônicos de 1,5 ml para a extração de proteínas. Este procedimento foi realizado no mesmo dia da coleta.

Os períodos gestacionais foram estimados conforme metodologia preconizada por Evans e Sack (1973) e Noden e Lahunta (1972) com mensuração da distância occípto-sacral, tomando como referência a crista nucal numa extremidade e a última vértebra sacral na extremidade oposta (Crown-Rump / CR). Essa mensuração foi realizada utilizando-se um paquímetro com divisões em milímetros. Após a mensuração, os embriões foram agrupados, conforme suas medidas, nos períodos gestacionais mostrados no tabela 1. 
Tabela 1- Período gestacional estimado segundo o Crow-rump dos embriões

PERÍODO GESTACIONAL (dias)

$0 \bullet----\bullet 15$

$15 \cdot----\bullet 20$

$20 \bullet----\bullet 30$

$30 \bullet---\cdot \bullet 40$

$40 \bullet---\cdot \bullet 50$

$50 \bullet---\bullet 60$
CROW-RUMP (cm)

$$
0,0+/-0,4
$$

$0,71+/-0,17$

$1,23+/-0,13$

$1,90+/-0,27$

$2,79+/-0,19$

$3,76+/-0,52$

De alguns embriões obtiveram-se fotografias com o objetivo de identificar e documentar o saco vitelínico.

\subsection{EXTRAÇÃO DE PROTEÍNAS DO SACO VITELÍNICO E DO FÍGADO FETAL BOVINO PARA FORMAÇÃO DO EXTRATO}

Os fragmentos do saco vitelínico e do fígado fetal acondicionados em tubos cônicos de 1,5 ml com solução fisiológica, foram centrifugados rapidamente para desprezar a solução fisiológica, invertendo cada tubo.

Preparou-se então, uma solução de extração com DDT (500 $\mu$ le solução de extração ${ }^{1}+5 \mu$ le DDT) a qual foi fervida por mais de 2 minutos e adicionada (100 $\mu \mathrm{l} /$ tubo) aos tubos contendo amostras de saco vitelínico, estes foram fervidos por 2 minutos.

\begin{tabular}{lll}
\hline${ }^{1}$ DTT & Solução de extração & Sample Buffer \\
\hline $1,52 \mathrm{~g}$ de DTT & $1 \mathrm{~g}$ de SDS & $1,52 \mathrm{~g}$ Tris \\
$10 \mathrm{ml}$ de água destilada & $0,3362 \mathrm{~g}$ de EDTA & $20 \mathrm{ml}$ de glicerol \\
& $1,21 \mathrm{~g}$ Tris & $2 \mathrm{ml}$ de mercaptoetanol \\
& $100 \mathrm{ml}$ de água destilada & $1 \mathrm{mg}$ de BFB \\
& & $100 \mathrm{ml}$ água destilada \\
& & ph 6,8 \\
\hline
\end{tabular}


Em função do fato das amostras serem finas e delicadas, a fervura normalmente é suficiente para diluição do tecido. Nos casos em que restam fragmentos teciduais, usou-se a maceração com pistilo plástico nos tubos até dissolvição da amostra. Nas amostras de fígado esse uso foi rotineiro.

Depois da fervura, as amostras foram centrifugadas por 15 minutos a uma velocidade de $13,5 \mathrm{rpm}$. O sobrenadante foi transferido para novos tubos identificados e este considerado como extrato protéico puro e total das amostras. Para realização do Western Blot utilizou-se 1:1 deste extrato e do corante Sample Buffer. Esta diluição foi realizada em parte do extrato e congelada a $-20^{\circ} \mathrm{C}$.

Para o preparo dos extratos da amostra de fígado fetal, este foi picotado com auxilio de um bisturi, até que o mesmo ficasse de aspecto pastoso (ou micropedacinhos). O mesmo protocolo usado nas amostras de saco vitelínico, foi seguido para o preparo dos extratos do fígado fetal, só com a diferença que utilizou-se $200 \mu$ l de solução de extração, devido à maior quantidade de tecido.

\subsection{ELETROFORESE EM GEL DE POLIACRILAMIDA PARA WESTERN BLOT (WB)}

A metodologia empregada foi baseada no trabalho de Laemmli (1970).

As alíquotas de extrato total e de proteína diluídas 1:1 em Sample Buffer foram descongeladas, e o volume a ser usado foi separado (20 $\mu \mathrm{l} /$ pocinho), ferveu-se por mais de 2 minutos e centrifugou-as antes de aplicá-las no gel.

\subsubsection{Preparo dos géis}

Inicialmente montou-se o sistema com duas placas de vidros, limpas com álcool 70\% e presas com uma garra, para a aplicação dos géis. 
Para o preparo dos géis, foram testados três protocolos (I, II e III), que diferiram na concentração dos reagentes e no tempo de corrida das amostras (Tabela 2) e com seus resultados (Tabela 3)

Tabela 2- Receita dos protocolos utilizados na preparação dos géis de poliacrilamida

\begin{tabular}{cccc}
\hline GÉIS & \multicolumn{3}{c}{ PROTOCOLOS } \\
\cline { 2 - 4 } & $\mathbf{1}$ & $\mathbf{2}$ & $\mathbf{3}$ \\
\hline GEL SEPARADOR \% & $\mathbf{1 0}$ & $\mathbf{6}$ & $\mathbf{6}$ \\
ÁGUA $(\mathrm{ml})$ & 4 & 4,3 & 5,245 \\
TAMPÃO BUFFER $(\mathrm{ml})$ & 2,5 & 7,5 & 2,5 \\
ACRILAMIDA 30\% $(\mathrm{ml})$ & 3,3 & 3 & 2 \\
TEMED $(\mu \mathrm{l})$ & 4 & 12 & 2,5 \\
APS $(\mu \mathrm{l})$ & 100 & 50 & 75 \\
STACKING GEL \% & $\mathbf{4}$ & $\mathbf{4}$ & $\mathbf{4}$ \\
ÁGUA $(\mathrm{ml})$ & 2,1 & 2,9 & 1,585 \\
TAMPÃO BUFFER $(\mathrm{ml})$ & 0,38 & 3,75 & 0,625 \\
ACRILAMIDA 30\% $(\mathrm{ml})$ & 0,5 & 0,75 & 0,2875 \\
TEMED $(\mu \mathrm{l})$ & 3 & 50 & 2,5 \\
APS 10\% $(\mu \mathrm{l})$ & 30 & 6 & 31 \\
\hline
\end{tabular}

\begin{tabular}{|c|c|c|}
\hline 2 & & \\
\hline Tampão Buffer- Gel 6\% e 10\% & Tampão Buffer- Gel4\% & Acrilamida (30\%) \\
\hline $6,05 \mathrm{~g}$ de Tris $(0,5 \mathrm{M})$ & $91 \mathrm{~g}$ de Tris $(1,5 \mathrm{M})$ & $30 \mathrm{~g}$ acrilamida \\
\hline $2 \mathrm{~g}$ de SDS $(0,4 \%)$ & $0,04 \mathrm{~g}$ de $\operatorname{SDS}(0,4 \%)$ & $0,3 \mathrm{~g}$ bisacrilamida \\
\hline $\begin{array}{l}500 \mathrm{ml} \text { de água destilada } \\
\text { ph } 8,7\end{array}$ & $\begin{array}{l}100 \mathrm{ml} \text { de água destilada } \\
\text { ph } 6,8\end{array}$ & $100 \mathrm{ml}$ de água destilada \\
\hline
\end{tabular}


Tabela 3 Resultado obtido e o período em que os diferentes protocolos para o preparo do gel de poliacrilamida foram preparados

\begin{tabular}{ccc}
\hline LABORATÓRIO & PERÍODO & RESULTADO DO GEL \\
\hline LITIAN & $07 / 2005$ & RUIM \\
PROTOCOLO I & $07 / 2005$ & RUIM \\
PROTOCOLO II & $08 / 2005$ & BOM \\
PROTOCOLO III & & \\
GENOMA & ---- & ---- \\
PROTOCOLO I & ---- & BOM \\
PROTOCOLO II & $06 / 2006-01 / 2007$ & \\
PROTOCOLO III & & \\
\hline
\end{tabular}

Com o protocolo I testado no laboratório LITIAN, não obtemos resultados positivos devido a não polimerização do gel, erro esse não encontrado. Por isso achou necessário o teste com outros protocolos, protocolos II e III. Com o protocolo II alguns géis polimerizaram, mas estes foram submetidos á um tempo muito elevado de corrida, prejudicando os resultados. Achou-se melhor que o gel fosse preparado com uma espessura maior, por isso passamos a utilizar o protocolo III, onde obtivemos resultados positivos, ou seja, a polimerização do gel.

Preparou-se primeiramente o gel 6\% seguindo a seqüência dos reagentes que estão indicados na tabela 2, por ultimo coloca-se o APS 10\% (10 ml de água Milli-Q + $1 g$ de APS) com água destilada para melhor polimerização. Após 40 minutos, depois de polimerizado o gel, retirou-se a água e o seu excesso com papel filtro para aplicação do gel concentrador. Após a aplicação, colocou-se o pente para a formação dos canais de aplicação das amostras, e esperou-se a polimerização por mais 20 minutos.

Depois de polimerizado o stacking gel, retirou-se o pente, lavou o sistema com água destilada abundante e secou o excesso com papel filtro. Colocou-se o sistema na cuba de eletroforese e completou com $500 \mathrm{ml}$ do tampão de corrida 
Reservoir $^{3}$ 1X (50 $\mathrm{ml}$ do tampão diluído em $450 \mathrm{ml}$ de água destilada), aplicou-se $20 \mu \mathrm{l}$ de cada amostras e $5 \mu \mathrm{l}$ do peso molecular. A quantidade aplicada de cada amostra foi definida devido a teste realizado anteriormente, onde tivemos resultados positivos. Foram utilizados Kaleidoskope (Bio-Rad, Kaleidoskope Prestained Standands 161-0324, $200 \mu \mathrm{l}$ ) e Biotinylated SDS Molecular Weight, Standard Mixture, Wide (6,500 - 180,000) (Sigma, B2787) como peso moleculares. Estes foram aplicados em géis diferentes. Segundo Bio-Rad (1610324) usa-se de 5 a $10 \mu \mathrm{l}$ do peso molecular para géis de 4-20\%, de acordo com o método de Laemmli et al. (1970).

Durante os o tempo de corrida, aproximadamente $100 \mathrm{mim}$, a voltagem nos primeiros 10 a 20 minutos foi de $70 \mathrm{~V}$ (volts) ate a compactação das proteínas, passando para $100 \mathrm{~V}$ e nos últimos 10 minutos para $120 \mathrm{~V}$.

Depois da corrida das amostras, desmontou-se o sistema e retirou-se o gel com o papel filtro, este foi corado com azul brilhante de Comassie Blue $(250 \mathrm{ml}$ metanol, $100 \mathrm{ml}$ de ácido acético, 0,5 g de Comassie Blue R-250 em água 1L destilada) por 2 horas e descorado em solução descorante (100 ml metanol, 150 $\mathrm{ml}$ ácido acético em 2L água destilada) por 100 minutos, sempre trocando, a cada 30 minutos, essa solução. Colocou-se o gel entre papel celofane e deixo-se secar overnight, depois scaneou-se o gel.

No gel preparado de acordo com o protocolo II, as amostras correram o gel por 3 horas numa voltagem de $120 \mathrm{~V}$.

\begin{tabular}{l}
$\overline{3}$ \\
\hline Tampão de eletroforese- Resovour Buffer (10X) \\
\hline 60,4 g Tris \\
288 g de glicina \\
20 g de SDS \\
2 I de água destilada \\
ph 8,3 \\
\hline
\end{tabular}




\subsubsection{Transferência para a Membrana de Nitrocelulose}

Depois de terminada a corrida do gel, preparou-se o tampão de transferência ${ }^{4}$ (100ml de tampão, 700ml de água e 200ml de álcool metílico). Deixou a membrana no tampão, agitando, por alguns minutos e montou-se o sistema de transferência ("sanduíche"). Para isso as esponjas e as folhas de papel filtro foram colocadas no tampão, abriu-se o sistema e coloco-se uma das esponjas úmidas, 3 folhas de papel filtro, o gel, em cima a membrana, mais três folhas de papel filtro úmidas e por ultimo outra esponja. Fechou-se o sistema, encaixou-se na cuba e colocou-se o tampão imediatamente. Correu-se por 1hora a 300 mA. Após a corrida, o sistema foi desmontado e a membrana retirada com auxílio de uma pinça, marcando o contorno da membrana e o local da primeira amostra com lápis. A membrana, entre papéis filme, foi deixada na estufa à $37^{\circ}$ para sua secagem.

No dia seguinte, lavou-se a membrana 3 vezes com água destilada. Depois a membrana foi corada com Ponceau (Sigma- P 7767) (0,1 g de Ponceau, $95 \mathrm{ml}$ de água destilada e $05 \mathrm{ml}$ de ácido acético), durante 15 minutos no agitador, para ter um idéia da qualidade da amostra e se a transferência foi bem feita, e depois esta foi lavada com água destilada e secada com papel filtro. Depois da transferência a membrana foi scaneda. A membrana foi descorada por 1 min no agitador com TTBS 0,1\% (10ml de TTBS 10X, 90ml de água e $50 \mu \mathrm{l}$ de Tween 20 0,05\%).

\begin{tabular}{l}
\hline 4 \\
\hline Tampão de transferência (10X) \\
\hline $142,6 \mathrm{~g}$ de glicina \\
$24,2 \mathrm{~g}$ de Tris \\
$10 \mathrm{~g}$ de SDS \\
1 I de água destilada \\
\hline
\end{tabular}




\subsubsection{Reação com Anticorpos}

Para a reação com os anticorpos, primeiramente a membrana foi deixada 1 hora agitando no leite desnatado 5\%. O anticorpo primário foi diluído em TTBS e aplicado na membrana onde ficou reagindo overnight. No dia seguinte a membrana foi lavada 3 vezes com TTBS $0,1 \%$, duas vezes rápidas e a terceira lavagem deixou-se agitando por 5 min.

O anticorpo secundário também foi diluído em TTBS, logo após foi aplicado na membrana onde ficou reagindo por 1 hora. Novamente lavou-se a membrana três vezes, duas vezes rápida e a terceira agitando por 5 min.

Utilizou-se anticorpo monoclonal anti-camundongo para alfafetoproteína humana, anticorpo anti-camundongo IgG para transferrina e o anticorpo policlonal anti-coelho para alfa1- antitripsina como anticorpos primário (Tabela 4) por não existir comercialmente o específico de bovino para esta proteína. Por ser o primeiro teste, foi utilizado uma concentração alta para ter certeza de que o anticorpo não deixaria de funcionar.

Como anticorpo secundário utilizou-se $o$ anticorpo anti-camundongo e anticoelho conjungado a peroxidase (Tabela 4) do kit ECL. Para a revelação do tipo colorimétrica por fosfatase alcalina, utilizou o. anticorpo anti-camundongo IgGfosfatase alcalina. 
Tabela 4 Relação entre os anticorpos utilizados, seu isotipo, hospedeiro, marca e diluição utilizada

\begin{tabular}{|c|c|c|c|c|}
\hline $\begin{array}{l}\text { ANTICORPOs } \\
\text { PRIMÁRIO }\end{array}$ & CLONE (isotipo) & HOSPEDEIRO & DILUIÇÃO & Cat.n $^{\circ}$ \\
\hline $\begin{array}{c}\text { Alfa fetoproteína } \\
\text { humana }\end{array}$ & Monoclonal/ IGg1 & camundongo & $1: 500$ & $\begin{array}{c}\text { Serotec(MCA1863HT) } \\
\text { Vector (VP-A104) }\end{array}$ \\
\hline $\begin{array}{l}\text { Alfa 1-antitripsina } \\
\text { humana }\end{array}$ & Policlonal IGg & coelho & 1:4 & Abcan (AB922) \\
\hline $\begin{array}{c}\text { Transferrina } \\
\text { humana }\end{array}$ & $\begin{array}{l}\text { Camundongo } \\
\text { IGg1 }\end{array}$ & camundongo & $1: 500$ e $1: 1000$ & BD (612124) \\
\hline $\begin{array}{l}\text { ANTICORPO } \\
\text { SECUNDÁRIO }\end{array}$ & & & & \\
\hline $\begin{array}{l}\text { Conjugado } \\
\text { peroxidase }\end{array}$ & IGg & $\begin{array}{c}\text { Camundongo e } \\
\text { coelho }\end{array}$ & $1: 2000$ & GE (NIF825) \\
\hline $\begin{array}{l}\text { Conjugado } \\
\text { fosfatase }\end{array}$ & IGg & Camundongo & 1:1000 & Sigma (A-5153) \\
\hline
\end{tabular}

4.4REVELAÇÃO - ECL

Para a revelação utilizou-se o Kit ECL ${ }^{\mathrm{TM}}$ Western Blotting Analyses Systen (GE Healthcare, RPN 2108).

Preparou-se 0,5 $\mathrm{ml}$ do detection reagente 1 e $0,5 \mathrm{ml}$ do detection reagent 2 , este foi agitado e colocado sobre a membrana. A membrana, no cassete, foi coberta com PVC. Na câmara escura, colocou-se uma folha de filme (Kodak MXG/PLUS 645 1074) dentro do cassete (Hyper cassete ${ }^{T M}$ RPN 13642), fechou e deixou expondo por 10 minutos. Após esse tempo o filme foi colocado no revelador. Após aparecer as bandas, lavou-se em água corrente e passou para o fixador por alguns segundos. Depois de seco, o filme foi colocado em cima da membrana para marcar, com uma caneta, o peso molecular. Essa etapa terminou com o scaneamento do filme para a análise dos resultados. 


\subsection{REVELAÇÃO - FOSFATASE ALCALINA}

Para esta revelação, colocou-se a membrana de nitrocelulose, após a reação com os anticorpos, em $30 \mathrm{ml}$ de tampão $A P^{5}$ e acrescentou-se $300 \mu \mathrm{l}$ de BCIP $^{6}$ (bromo chloro endolylphosphate- Sigma B3679) e $300 \mu$ de NBT $^{7}$ (nitro blue tetrazolium- Sigma 6876). Deixou agitando por 5 minutos até aparecerem as bandas, em seguida lavou a membrana em água destilada e secou-a em papel filtro.

\subsection{QUANTIFICAÇÃO DAS PROTEÍNAS}

A quantificação das proteínas foi realizada através do kit Quick stard Bradford protein Assay (BioRad).

Identificou-se tubos cônicos de 1,5 ml para os diferentes padrões de BSA nas concentrações, $2.0,1.5,1.0,0.75,0.25,0.125 \mathrm{mg} / \mathrm{ml}$, e para as amostras a serem quantificadas. Em cada tubo colocou $500 \mathrm{ml}$ do reagente de Bradford (1X) e

5

Tampão A.P

$12,11 \mathrm{~g}$ de Tris

$1,02 \mathrm{~g}$ de $\mathrm{MgCl}_{2}$

$5,84 \mathrm{~g}$ de $\mathrm{NaCl}$ em $1 \mathrm{~L}$ de água destilada

\begin{tabular}{l} 
6 \\
\hline BCIP \\
$10,165 \mathrm{~g}$ de BCIP \\
\hline 7 \\
\hline NBT \\
\hline $0,33 \mathrm{~g}$ de NBT \\
$7,0 \mathrm{ml}$ de DMF \\
$3,0 \mathrm{ml}$ de água \\
\hline
\end{tabular}


$10 \mu \mathrm{l}$ de cada amostra e de cada concentração de do BSA e agitou no vórtex. Em um dos tubos havia apenas o reagente de Bradford $(0 \mathrm{mg} / \mathrm{ml})$.

A leitura foi realizada no espectrofotômetro, onde as absorbâncias foram medidas a $595 \mathrm{~nm}$.

Na cubeta de diamante $(500 \mathrm{ml})$ colocou primeiramente a solução que continha apenas o reagente de Bradford e mediu a absorvância, para zerar o equipamento, depois lavou o tudo com água destilada e foi mediando as absorbâncias das diferentes concentrações de BSA, e em seguida as absorbâncias das amostras do saco vitelínico dos embriões coletados.

Para a construção do gráfico, construiu-se a curva padrão com base nas leituras de absorbância das respectivas diluições de BSA. Plotou-se os valores de absorvância a 595 nm no eixo y, e a concentração em $\mu \mathrm{g} / \mathrm{ml}$ no eixo x. Para determinar a concentração das amostras usou-se a curva padrão obtida. 


\section{RESULTADOS}

Os resultados a seguir referem-se à descrição macroscópica do saco vitelínico e a análise e quantificação das proteínas alfafetoproteína, alfa 1antitripsina e transferrina.

\subsection{EMBRIÕES COLETADOS}

Os embriões coletados foram separados em relação ao tamanho e o período gestacional, como mostra o tabela 5. 
Tabela 5- Relação entre o período gestacional estimado e o tamanho dos embriões coletados.

\begin{tabular}{ccc}
\hline Embrião & Tamanho $(\mathrm{cm})$ & Período gestacional (dias) \\
\hline Embrião 1 & 0,87 & 15 --- 20 \\
Embrião 2 & 1,3 & 20 --- 30 \\
Embrião 3 & 1,73 & 30 --- 40 \\
Embrião 4 & 3,62 & 50 --- 60 \\
Embrião 5 & 2,1 & 30 --- 40 \\
Embrião 6 & 2,01 & 30 --- 40 \\
Embrião 7 & 0,4 & 0 --- 15 \\
Embrião 8 & 3,4 & 50 --- 60 \\
Embrião 9 & 3,3 & 50 --- 60 \\
Embrião 10 & 0,2 & 0 --- 15 \\
Embrião 11 & 1,9 & 30 --- 40 \\
Embrião 12 & 1,3 & 20 --- 30 \\
Embrião 13 & 1,7 & 30 --- 40 \\
Embrião 14 & 2,2 & 30 --- 40 \\
Embrião 15 & 1,9 & 30 --- 40 \\
Embrião 16 & 2,9 & 40 --- 50 \\
Embrião 17 & 3,5 & 50 --- 60 \\
Embrião 18 & 0,60 & 10 --- 20 \\
Embrião 19 & 1,25 & 20 --- 30 \\
Embrião 20 & 1,75 & $40--50$ \\
Embrião 21 & 2,77 &
\end{tabular}




\subsection{DESCRIÇÃO MACROSCÓPICA DO SACO VITELÍNICO}

Com relação às membranas fetais analisadas, o cório mostrou-se sem vascularização, sendo a membrana mais externa. O alantóide apresenta-se como uma membrana transparente, totalmente separado do cório, com poucos vasos sanguíneos. O âmnio, uma membrana também transparente envolve o embrião e não apresenta vasos sanguíneos em sua superfície (Figura 1 e 2). O saco vitelínico, uma membrana fina e transparente, mostra-se bastante desenvolvido até 40 dias de gestação (Figura 3), estando próximo aos vasos umbilicais do embrião e conectado ao intestino do embrião. $O$ seu tamanho diminui drasticamente, ficando difícil sua visualização a partir dos 50 dias de gestação, onde o processo de involução está bem caracterizado, tornado-se uma membrana bem fina e transparente. 

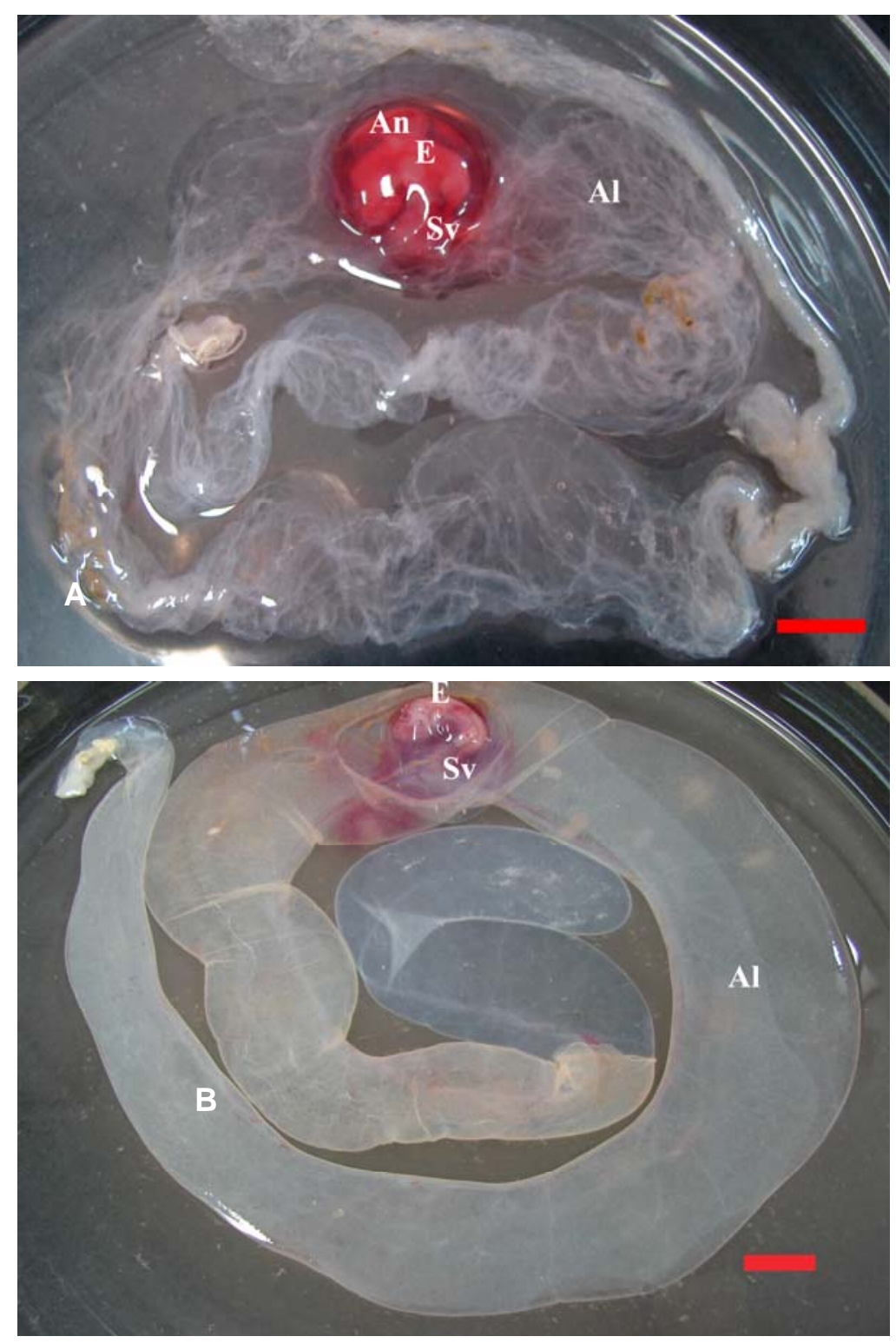

Figura 1- Em A e B embriões bovinos e suas,membranas fetais. Em A embrião com 0,87 cm de CR (15 a 20 dias), em $B$ embrião $1,3 \mathrm{~cm}$ de $\mathrm{CR}$ (20 a 30 diasEm A e B embrião (E), alantóide (Al), âmnio (An) e saco vitelínico (Sv) .Equivalente a 1 

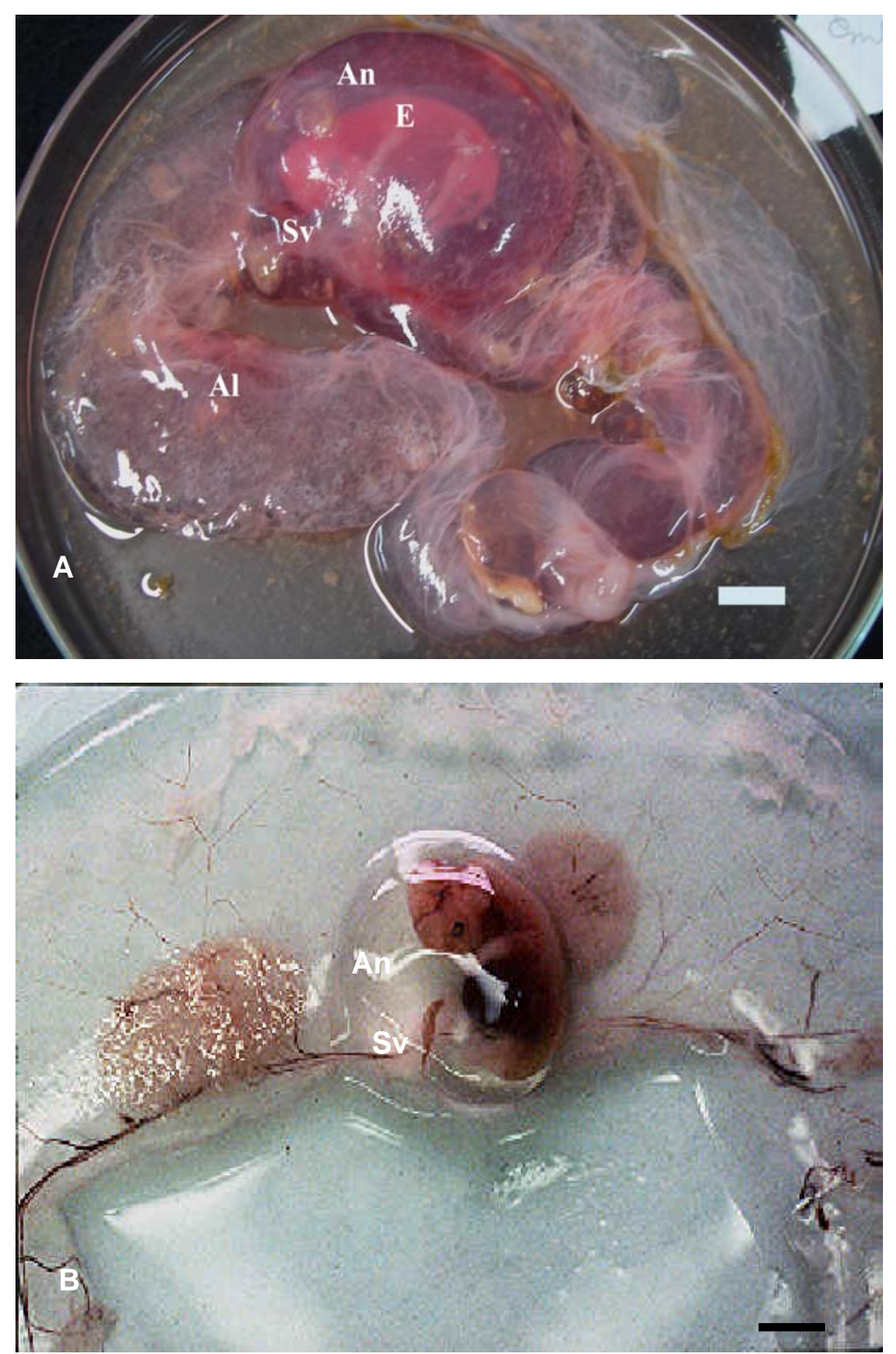

Figura 2- Em A e B embriões bovinos e suas,membranas fetais. Em A com 1,75 cm de CR (30 a 40 dias) e em B com 3,62 cm de CR (50 a 60 dias). Em A e B embrião (E), alantóide (Al), âmnio (An) e saco vitelínico (Sv). Equiovalente a $1 \mathrm{~cm}$ 


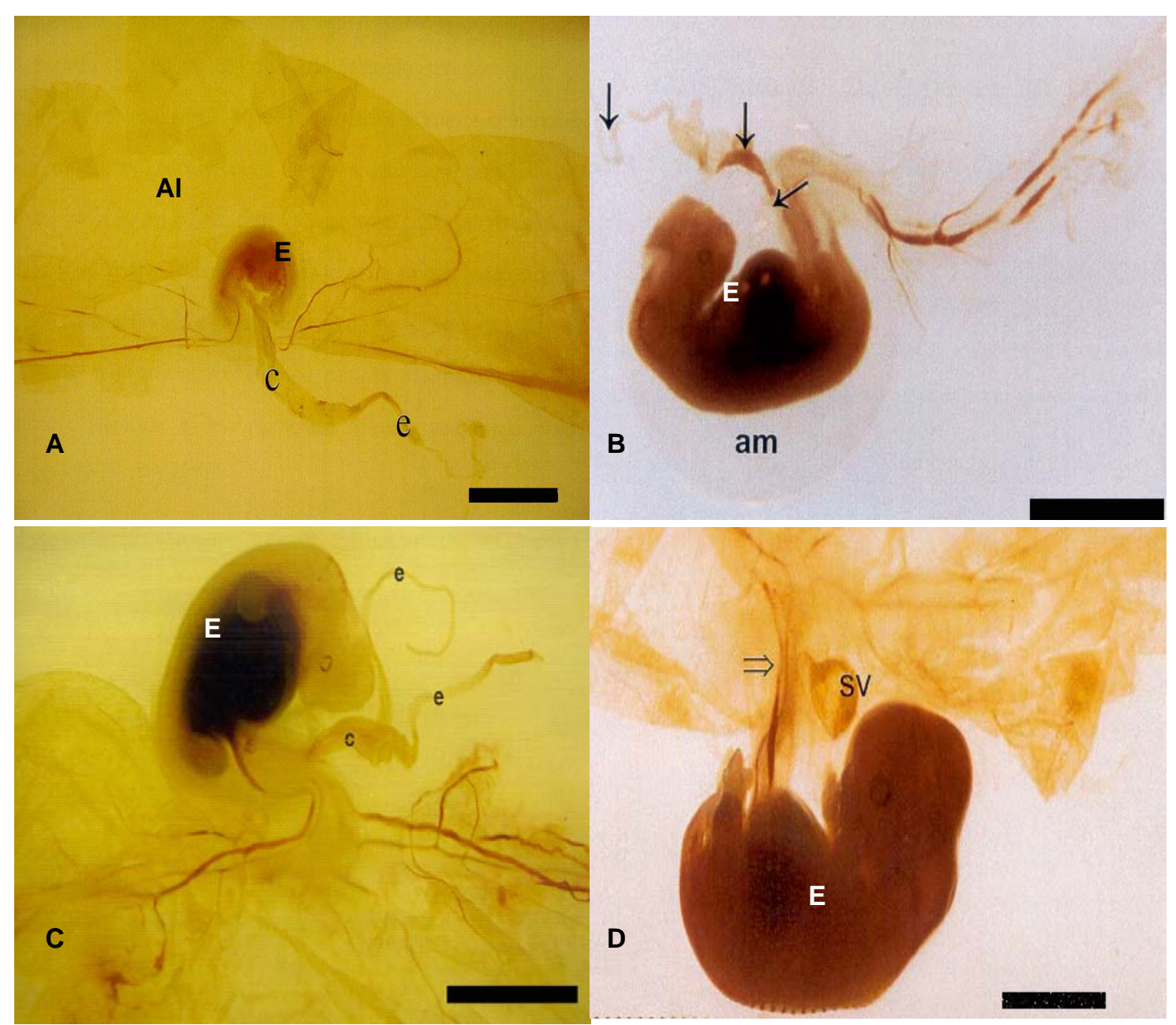

Figura 3-A-D embrião bovinos $(E)$ em diferentes períodos gestacionais. Em $A$, embrião com $0,60 \mathrm{~cm}$ de CR (10 a 20 dias), mostrando o alantóide (Al), e parte central (c)e extremidade (e) do saco vitelínico. Em B embrião com 1,25 cm de CR (20 a 30 dias), onde observamos o saco vitelínico (setas) e âmnio (am). Em C embrião com $1,75 \mathrm{~cm}$ (30 a 40 dias) ainda com presença do saco vitelínico, parte central (c) e extremidades (e). Em D embrião com 2,77cm (40 a 50 dias), mostrando o saco vitelínico bastante reduzido (Sv) e o cordão umbilical (seta). Equivalente a $1 \mathrm{~cm}$ 


\section{3- ANÁLISE DAS PROTEÍNAS}

Após a corrida e transferência em SDS-PAGE nossos resultados mostraram-se não reativos com os anticorpos específicos utilizados. Provavelmente o resultado negativo obtido resultante do protocolo $\mathrm{II}$, está relacionado ao tempo elevado de corrida das amostras (3 horas) prejudicando assim a análise dos resultados, pois as proteínas de interesse são proteínas de peso molecular pequeno. Nesse protocolo foram utilizados as amostras relacionadas ao saco vitelínico dos embriões 1 e 2 (tabela. 01). O gel foi corado com Comassie Blue, e assim podemos observar apenas o peso molecular Biotinylated SDS Molecular Weight (Figura. 4 A1 e A2).
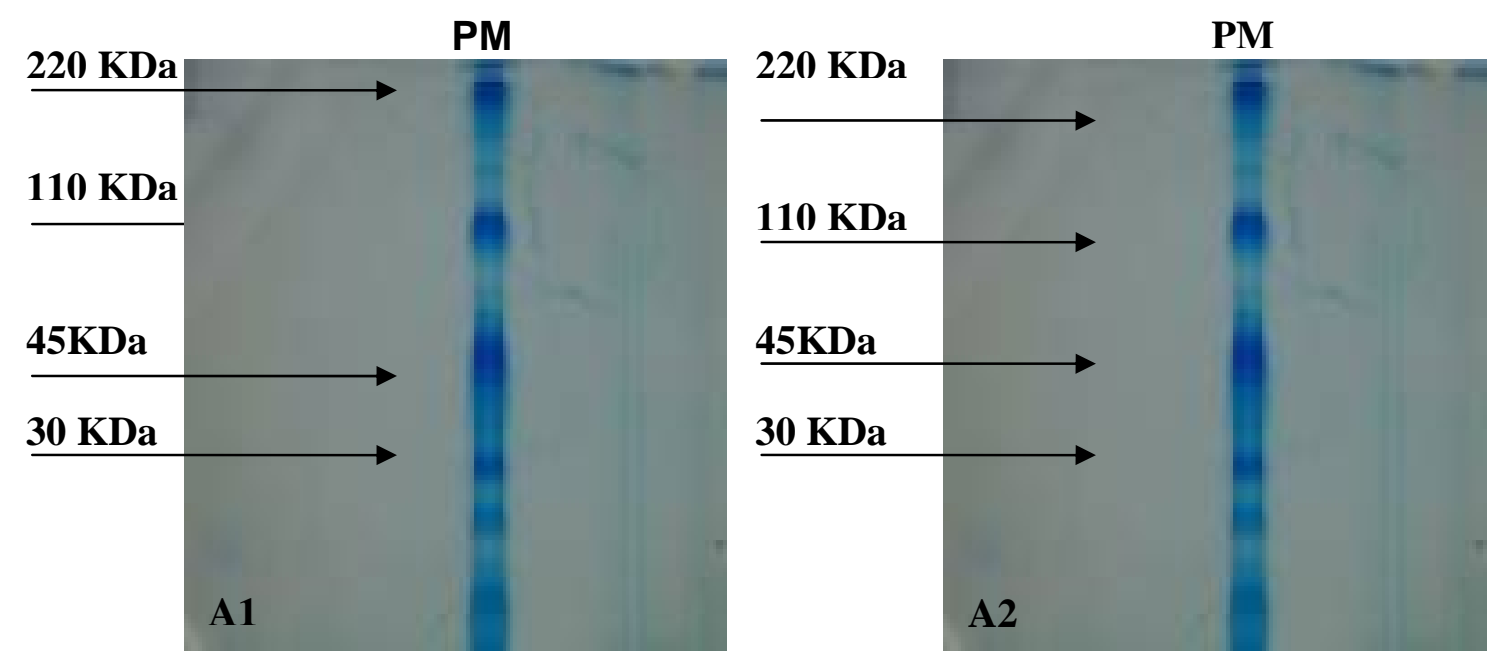

Figura 4 A1 e A2- Géis de poliacrilamida (SDS-PAGE) $6 \%$ corado com Comassie Blue, mostrando apenas o peso molecular (PM) 
As amostras do saco vitelínico dos embriões 3 e 4 (tabela 1) foram aplicadas no gel, que foi preparado de acordo com o protocolo III. Não obtivemos resultados positivos devido a não polimerização dos géis.

Por outro lado, as amostras dos sacos vitelínicos dos embriões 5 e 6 (que correspondem ao período gestacional de (30 a 40 dias), o gel separador de $6 \%$ e o stacking gel $4 \%$ preparados para eletroforese e Western Blot estavam de acordo com o protocolo 3. O gel também foi corado com Comassie Blue (Figura 5A), onde podemos observar o rasto das proteínas e a presença de algumas bandas, e a membrana após a transferência, corada com Ponceau onde também visualizamos a presença de proteínas(Figura 5B) anticorpo primário monoclonal anticamundongo para alfafetoproteína humana 1:500 e secundário conjungado com peroxidase anti camundongo 1:1000 para a revelação com ECL. Apos a revelação tivemos um resultado positivo, onde podemos observar a proteína $\alpha$ - fetoproteína, que e uma glicoproteina de peso molecular de aproximadamente 70KDa (Figura $6)$. 


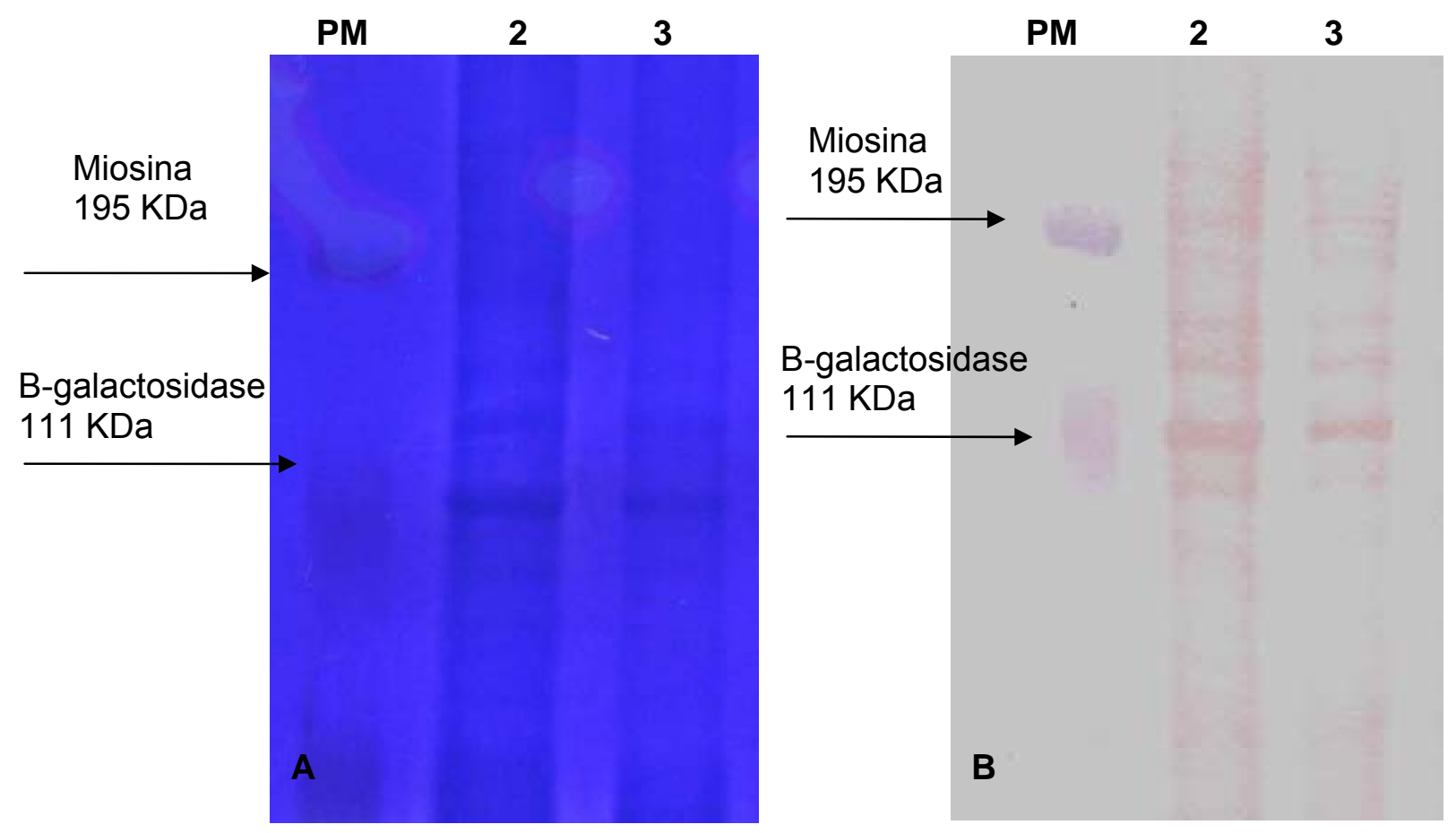

Figura 5- Em A, gel SDS-PAGE 6\% corado com Comassie Blue, mostrando o peso molecular (PM). Em 2 e 3 amostras do saco vitelínico de embrião bovino no período gestacional estimando de 30 a 40 dias. Em B, membrana de nitrocelulose corada com Ponceau. 


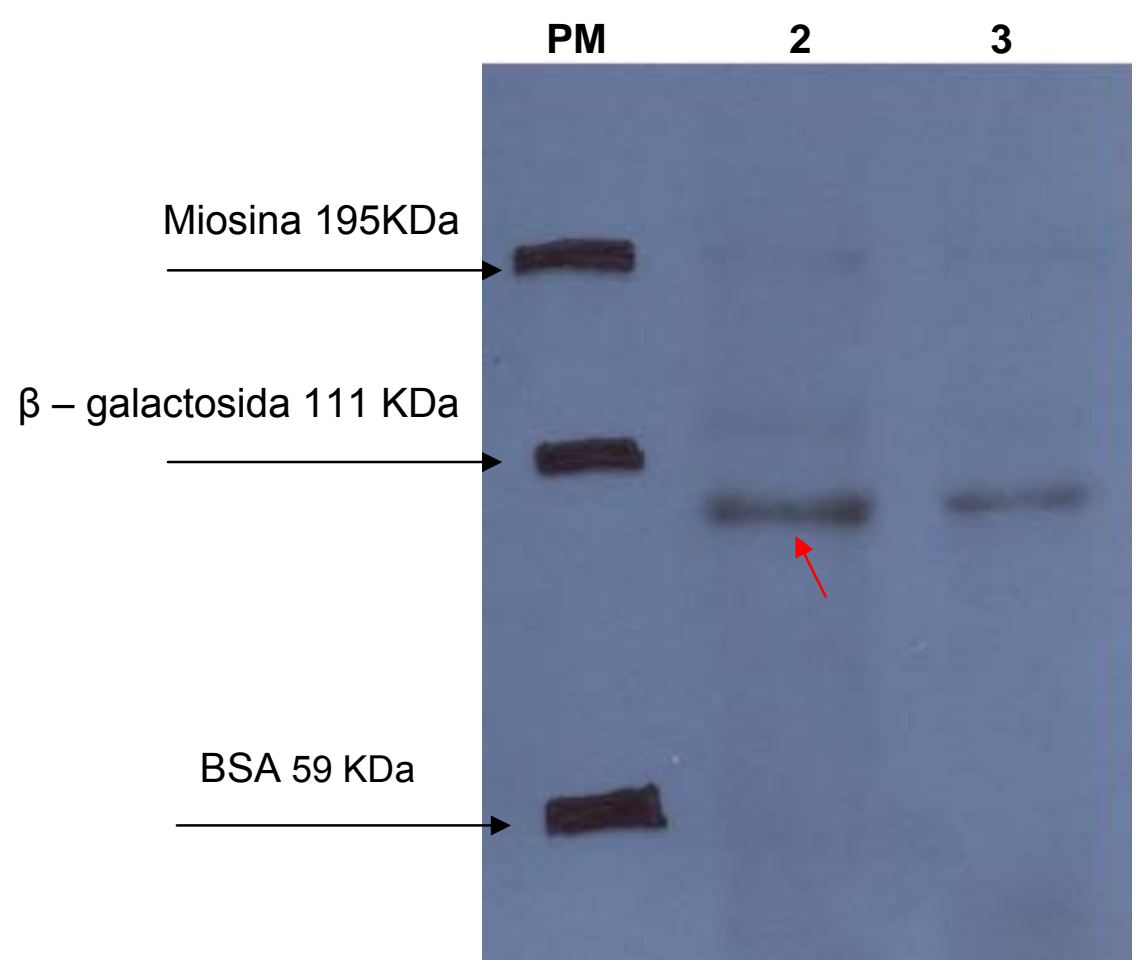

Figura 6 - Membrana após a revelação do tipo ECL, mostrando o peso molecular (PM) e as amostras do saco vitelínico dos embriões 2 e 3 no período gestacional estimado de 30 a 40 dias, as setas vermelhas indicam a $\alpha$-fetoproteína, nas amostras 2 e 3 , com peso molecular de $70 \mathrm{Kda}$. 
Foi realizada eletroforese em gel de poliacrilamida com gel separador de $6 \%$ e o stacking gel $4 \%$ para a técnica de Western Blot. As amostras aplicadas no gel, de acordo com a figura 6 foram, o peso molecular Kaleidoskope ${ }^{R}$, as amostras do saco vitelínico dos embriões 7, 8, 9 e 10. As amostras correram o gel por 1 hora e $30 \mathrm{~min}$, sendo os primeiros $20 \mathrm{~min}$ a $70 \mathrm{~V}, 70 \mathrm{~min}$ a $100 \mathrm{~V}$ e os últimos 10 min a 120V. Depois da transferência para a membrana de nitrocelulose, esta foi corada com Ponceau (Figura 7), onde observamos a presença dos rastros das proteínas, confirmando a presença desta através das bandas. A membrana foi bloqueada com leite $5 \%$ e reação com anticorpo monoclonal anti-camundongo para alfafetoproteína humana overnight 1:500. O anticorpo secundário conjugado com perodidase anti-camundongo 1:1000, reagiu por $1 \mathrm{~h}$ Não houve resultado positivo após revelação do tipo ECL, já que não foram visualizadas bandas.

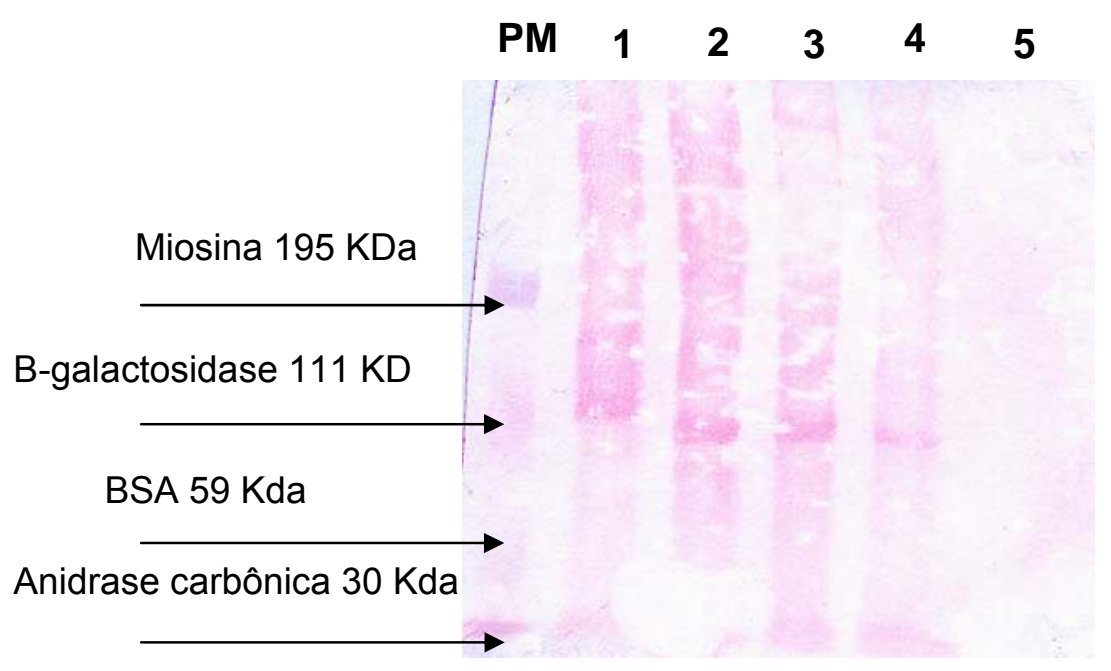

Figura 7- Membrana de nitrocelulose corada com ponceau, mostrando o peso molecular (PM) e as amostras do saco vitelínico de embriões bovinos ( 1 a 3 ). em 1 e 4 embriões com período estimado de 0 a 15 dias, 2 e 3 com 50 a 60 dias de gestação. 
Foi testado o anticorpo primário anticorpo monoclonal para alfafetoproteina 1:500 através da técnica de Western Blot. Foi preparado gel de poliacrilamida a $6 \%$ e a aplicação das amostras seguiu a seguinte ordem: peso molecular Kaleidoskope ${ }^{R}$, fígado fetal, amostras dos embriões 7, 8, 9, 10, 11, 12 , 13, 14, 15 e dos embriões 5 e 6 que serviram como controle (pois obtivemos resultados positivos anteriormente). As amostras correram no gel por 1 hora e 30 min, sendo os primeiros $20 \mathrm{~min}$ a $70 \mathrm{~V}, 70 \mathrm{~min}$ a $100 \mathrm{~V}$ e os últimos $10 \mathrm{~min}$ a $120 \mathrm{~V}$. A membrana foi corada com ponceau, mas não houve marcação dos rastros das proteínas. Após a transferência a membrana foi bloqueada com solução tampão contendo $5 \%$ leite desnatado e a reação de ligação às proteínas específicas com anticorpo primário monoclonal anti-camundongo para alfafetoproteína humana 1:500 overnight e reveladas com o anticorpo secundário com anticorpo secundário conjugado com fosfatase alcalina 1:1000 por 1 hora, para a revelação do tipo colorimétrica-Fosfatase alcalina. 
Foi realizada um novo Western Blot com eletroforese em gel de poliacrilamida o gel separador de $6 \%$ e o stacking gel $4 \%$ segundo o protocolo 3 . As amostras que correram o gel foram: peso molecular Kaleidoskope ${ }^{R}$, fígado fetal, e amostras do saco vitelínico dos embriões $7,8,9,10,11,12,13$ e 14 na seqüência em que aparecem na figura abaixo (Figura 8) . A eletroforese durou 2 horas e $20 \mathrm{~min}$ a 100V. A membrana foi corada com Ponceau (Figura 7). Reagíamos a membrana com o anticorpo primário monoclonal anti-camundongo para alfafetoproteína humana 1:500, overnight e com anticorpo secundário anticamundongo conjugado com fosfatase alcalina 1:1000 por 1 hora. A revelação foi do tipo colorimétrica-Fosfatase alcalina. Depois da revelação não houve reação visível de bandas.

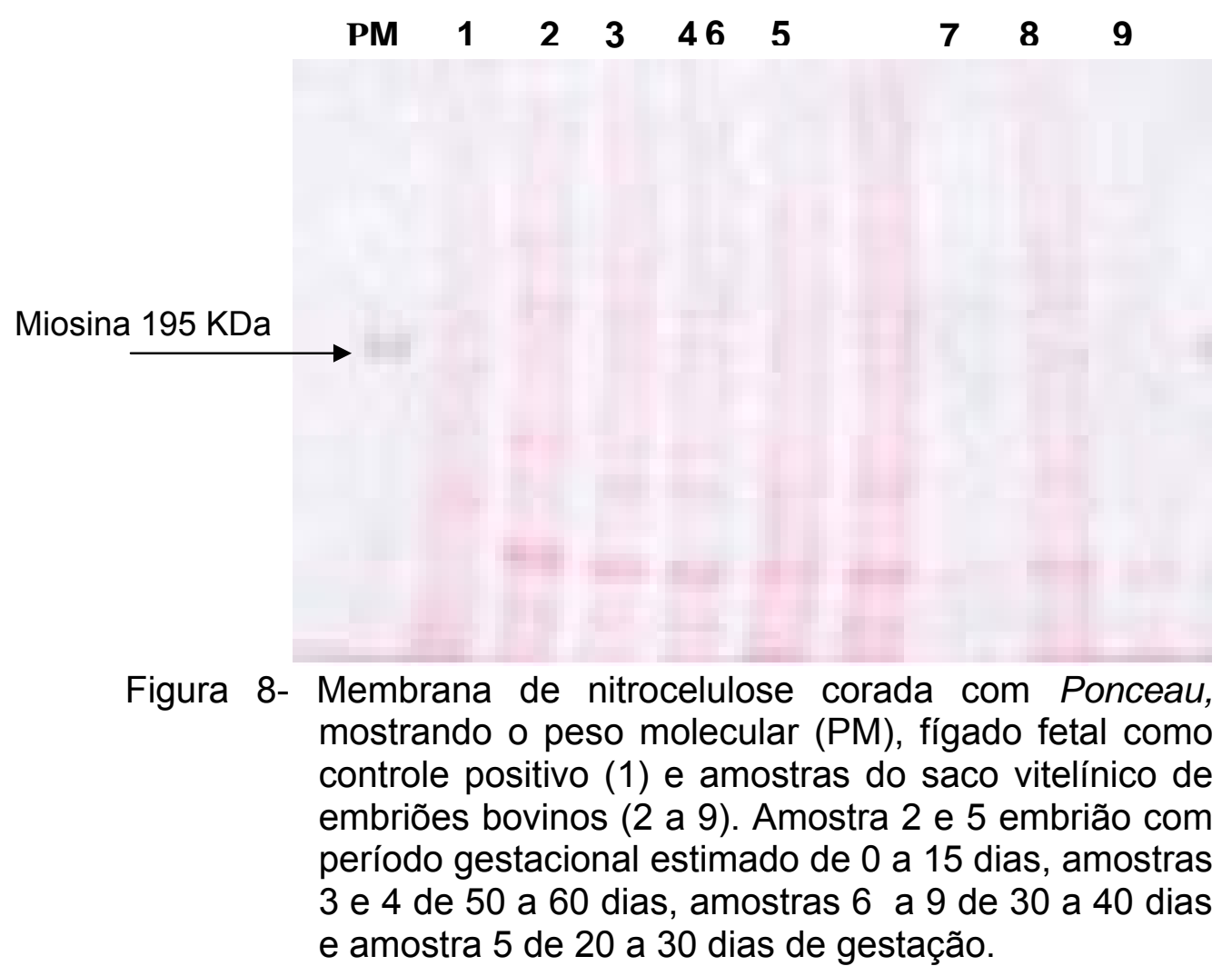


Foi realizado um Western Blot para testar um novo anticorpo primário monoclonal anti-camundongo para alfafetoproteína humana 1:500 e para testar anticorpo primário anti-camundongo IgG para transferrina 1:1000. Os géis preparados, $6 \%$ e $4 \%$, seguiram o protocolo 3 . A eletroforese durou $85 \mathrm{~min}$. As amostras utilizadas, na seqüência em que aparecem na figura abaixo (Figura 9) foram peso molecular Kaleidoskope ${ }^{R}$, amostra do saco vitelínico do embrião 05 , $09,11,16$. As amostras correram o gel por $85 \mathrm{~min}$ a $100 \mathrm{~V}$, sendo os primeiros 10 min a $70 \mathrm{~V}$. A membrana foi corada com Ponceau. A revelação foi do tipo $\mathrm{ECl}$ com a reação com anticorpo secundário conjugado com peroxidase anti mouse na concentração 1:2000. Novamente na revelação nada apareceu. Como não reação do anticorpo com a proteína de interesse, reagimos a membrana novamente com anticorpo secundário conjugado para fosfatase alcalina 1:1000, para testarmos a revelação colorimétrica, mas também não obtivemos resultados.

\section{$\begin{array}{llllllllll}\mathrm{PM} & 1 & 2 & 3 & 4 & \mathrm{PM} & 1 & 2 & 3 & 4\end{array}$}

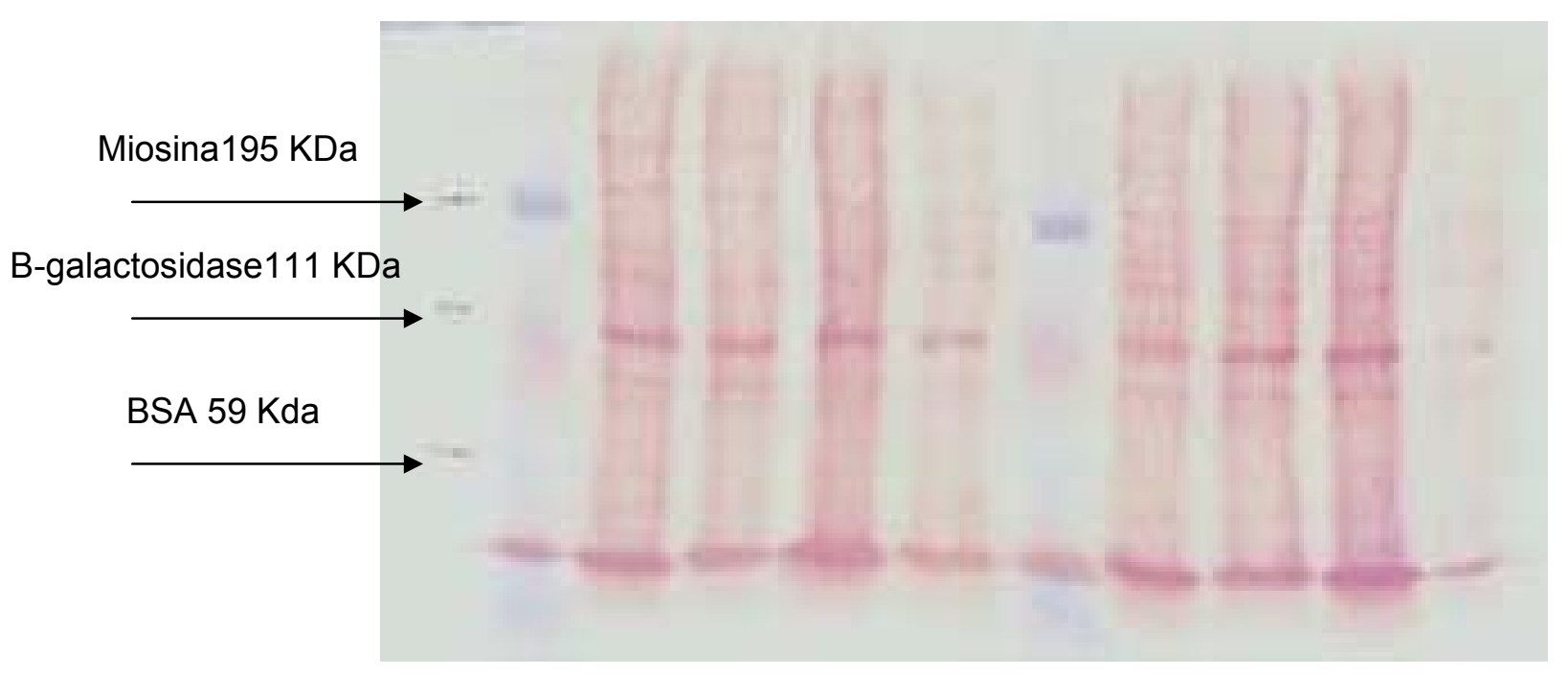

Figura 9- Membrana de nitrocelulose corada com Ponceau, mostrando o peso molecular Kaleidoskope (PM), e amostras do saco vitelínico de embriões bovinos (1 a 4). Amostras 1, 3 e 4 embriões no período gestacional estimado de 30 a 40 dias, amostra 2 de 50 a 60 dias gestação. 
Foram preparados dois géis para Westen Blot e para eletroforese em gel de poliacrilamida com gel separador de $6 \%$ e stacking gel á $4 \%$, seguindo a receita do protocolo 3. As amostras utilizadas, na seqüência em que são mostradas na figura 09, foram peso molecular Kaleidoskope ${ }^{R}$, saco vitelínico do embrião 07, 06, $08,10,12,13,14,16$ e 17. A eletroforese durou $85 \mathrm{~min}$ a $100 \mathrm{~V}$, sendo os primeiros 20 min a 70V. A membrana corada com ponceau (Figura 10) indica as bandas protéicas das diferentes amostras. No outro gel, que correu ao mesmo tempo, aparentemente não ocorreu a transferência $O$ anticorpo anti-camundongo IgG para transferrina 1:1000 overnight. Primeiramente fez-se a revelação do tipo ECL com o anticorpo secundário conjugado para peroxidase 1:2000, por 1 hora.

Após a revelação podemos observar umas bandas bem fracas, bandas de menor intensidade ou ratividade ao anticorpo primário utilizado, próximas a $\mathrm{B}$ galactosidase de $111 \mathrm{KDa}$ (Figura 11). A transferrina é uma proteína de $85 \mathrm{Kda}$, em algumas amostras de saco vitelinico analisadas também foi encontrada a transferrina, comprovando assim que este anticorpo reage com a proteína bovina. Para uma melhor visualização das bandas reagimos a membrana novamente com anticorpo anti-camundongo IgG para transferrina, overnight, e com o anticorpo secundário conjugado para peroxidase, mas depois da revelação por $\mathrm{ECl}$ nada apareceu. Então reagimos a membrana com anticorpo secundário anti-mouse lgGAlkaline Fosfatase para testarmos a revelação colorimétrica, mas o resultado foi não reativo nas condições utilizadas neste protocolo. 


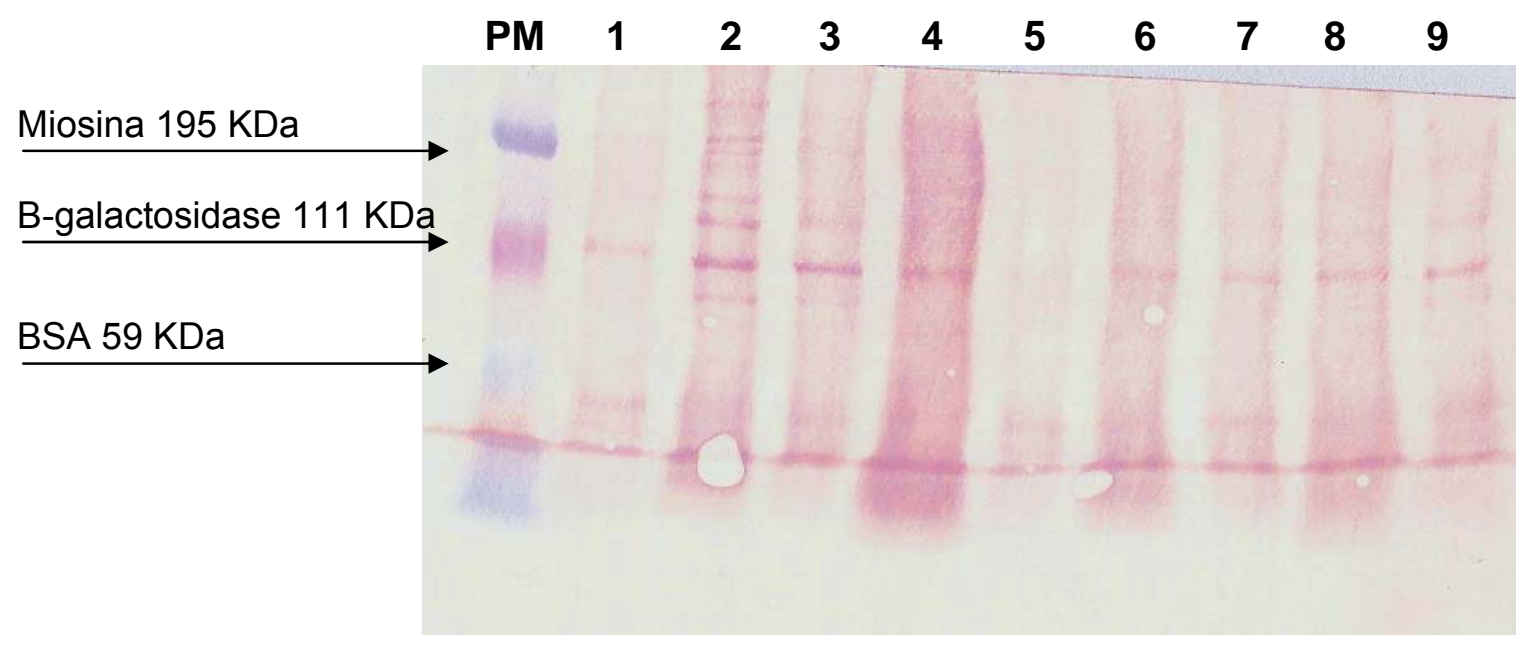

Figura 10- Membrana de nitrocelulose corada com ponceau, mostrando o peso molecular kaleidoskope (PM) e as amostras do saco vitelínico de embriões bovinos (1 a 10). Amostras 1 e 4 embriões com período estimado de 0 a 15 dias, amostras 2, 6, e 7 de 30 a 40 dias, amostras 3 e 9 de 50 a 60 dias, amostra 5 de 20 a 30 dias e amostra 8 de 40 a 50 dias de gestação.

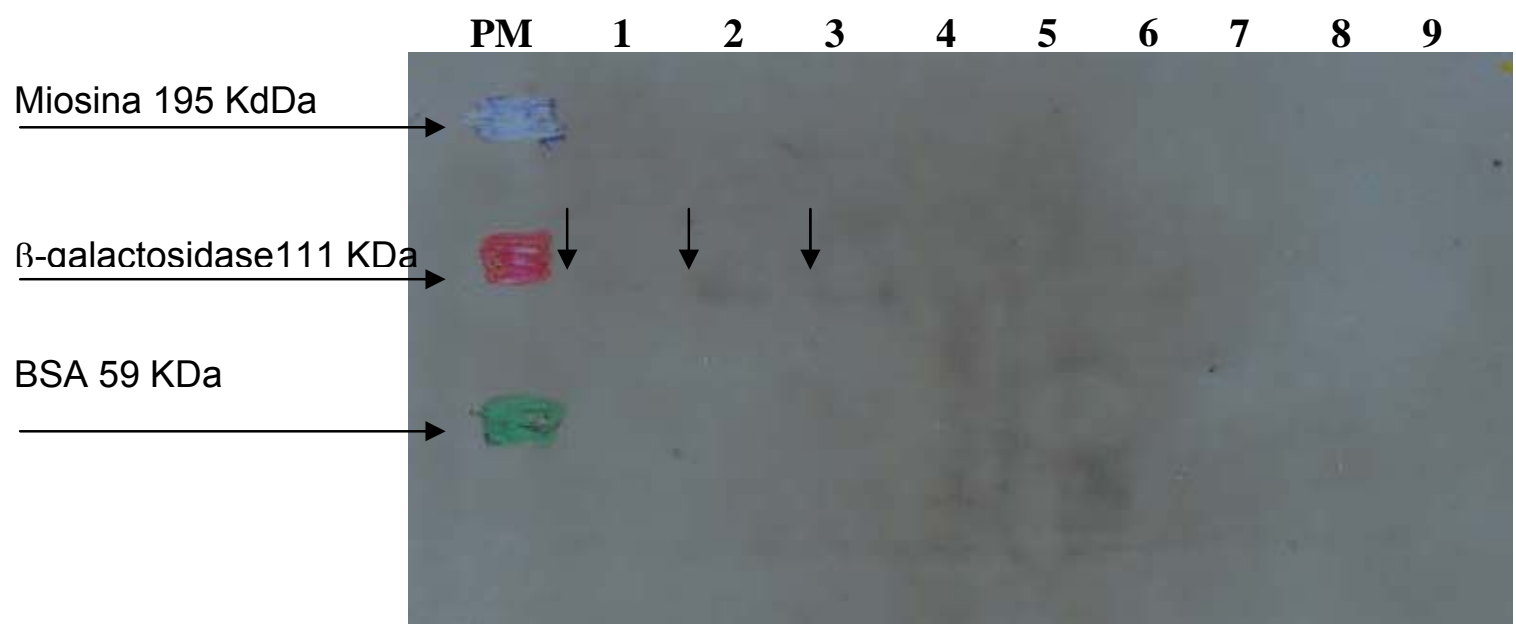

Figura 11- Filme após a revelação do tipo ECL, mostrando o peso molecular (PM), e as amostras do saco vitelínico de embriões bovinos (1 a 10). Amostra 1 e 4 embriões com período estimado de 0 a 15 dias, amostras 2, 6, e 7 de 30 a 40 dias, amostras 3 e 9 de 50 a 60 dias, amostra 5 de 20 a 30 dias e amostra 8 de 40 a 50 dias de gestação. As setas indicam a proteína transferrina de $85 \mathrm{KDa}$. 
Para comparar os diferentes períodos gestacionais realizou-se eletroforese em gel de poliacrilamida com gel separador de $6 \%$ e o stacking gel $4 \%$, de acordo o protocolo 3, aplicando assim uma amostra de cada período gestacional. As amostras aplicadas no gel, na seqüência em que aparecem na figura 12, são o peso molecular Kaleidoskope ${ }^{R}$, amostras dos embriões 9, 16, 15, 12, 7 e 10 e amostra de fígado fetal. O gel, após a corrida de $110 \mathrm{~min}$, nos primeiros $20 \mathrm{~min}$ a $70 \mathrm{~V}, 70 \mathrm{~min}$ a $100 \mathrm{~V}$ e os últimos $10 \mathrm{~min}$ a $120 \mathrm{~V}$, foi corado com Comassie Blue (Figura 12) por 1 hora e descorado overnight com água destilada.

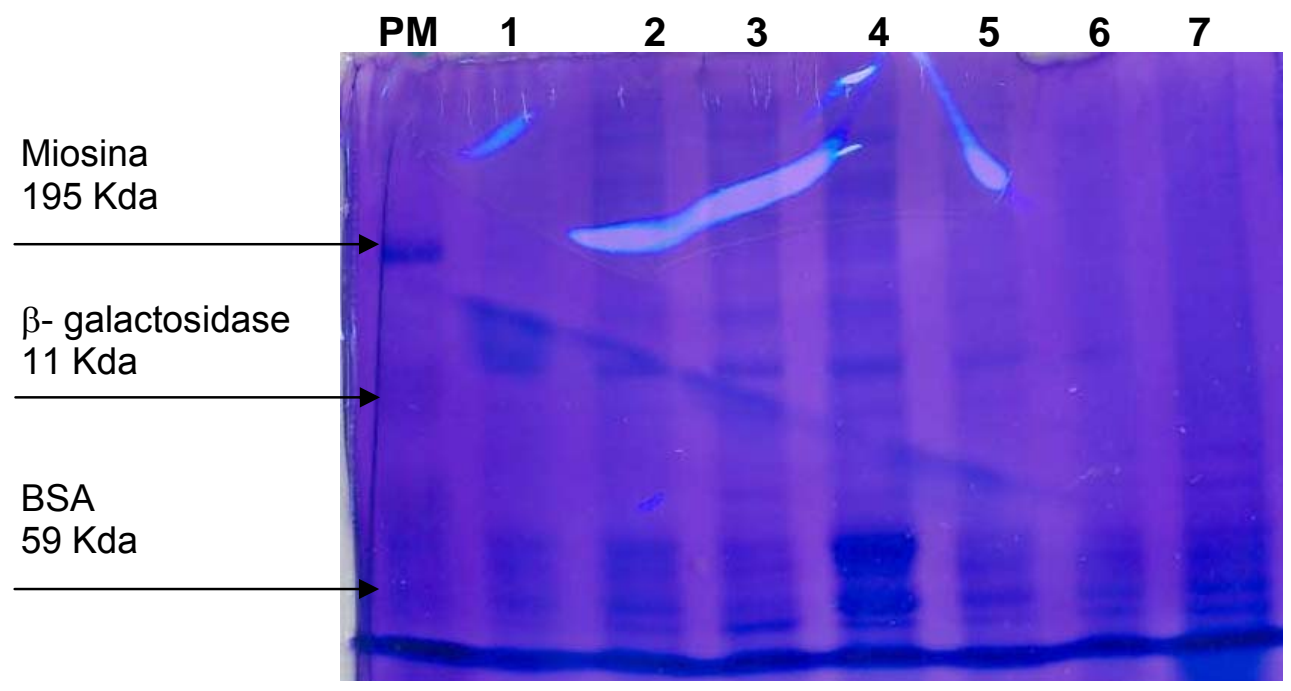

Figura12- Gel SDS-PAGE 6\%, corado com Comassie Blue, mostrando peso molecular (PM), e amostras do saco vitelínico de embriões bovinos (1 a 6). Amostras 1 embriões no perdido gestacional estimado de 50-60 dias gestação, amostra 2 de 40 a 50 dias, amostras 3 e 4 de 30-40 dias amostras 5 e 6 de 0-15 dias e amostra 6 , fígado fetal. 
Para testar novamente o anticorpo primário monoclonal anti-camundongo para alfafetoproteína humana realizamos um novo Western blot e eletroforese em gel de poliacrilamida com gel separador de $6 \%$ e o stacking gel $4 \%$, de acordo o protocolo 3. Foram aplicadas apenas algumas amostras, para testar o anticorpo. As amostras aplicadas foram peso molecular Kaleidoskope ${ }^{R}$, fígado, e amostras dos embriões 5, 8, 16. As amostras correram o gel por $100 \mathrm{~min}$, os primeiros 15 min a $70 \mathrm{~V}$, depois 1 hora a $100 \mathrm{~V}$ e os últimos $10 \mathrm{~min}$ a $120 \mathrm{~V}$. Após a transferência para a membrana de nitrocelulose, corou-se a membrana com Ponceau (Figura 13). Esta foi reagida com o anticorpo primário overnight, e com secundário conjugado com peroxidadse anti-camundongo 1:2000, durante uma hora. Após a revelação do tipo ECL, não foram identificadas bandas visíveis no filme radiográfico.

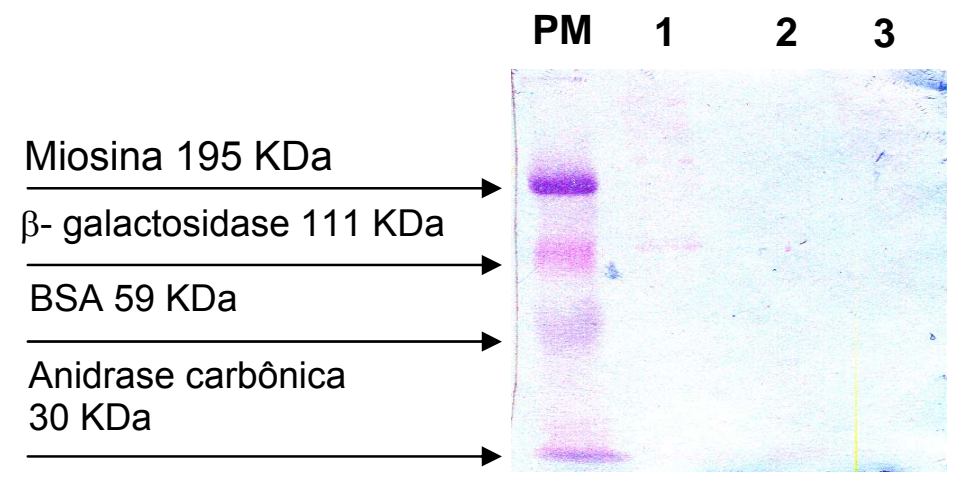

Figura13- Membrana de nitrocelulose corada com ponceau, mostrando o peso molecular (PM) e as amostras do saco vitelínico de embriões bovinos (1 a 3) Em 1 amostra de embrião com período estimado de 30 a 40 dias, 2 e 4 com 50 a 60 dias e 3 de 40 a 50 dias de gestação. 
Realizou-se um novo Western Blot para testar o anticorpo primário monoclonal para alfafetoproteína 1:500. Foram utilizadas algumas amostras como teste. Estas foram aplicadas no gel na seqüência, peso molecular Kaleidoskope ${ }^{R}$, amostra dos embriões 15, 16 e 17. O tempo de corrida das amostras durou 110 min, com os primeiros $20 \mathrm{~min}$ a $70 \mathrm{~V}$ e os últimos $10 \mathrm{~min}$ a $120 \mathrm{~V}$. Após a transferência para a membrana de nitrocelulose, esta foi corada com Ponceau para a visualização das bandas protéicas (Figura 14). O bloqueio foi feito com leite $5 \%$. Reagimos a membrana com o anticorpo primário overnight, e com o anticorpo secundário conjugado para peroxidase 1:2000, durante uma hora. A revelação foi do tipo ECl. Não obtivemos resultado positivo.

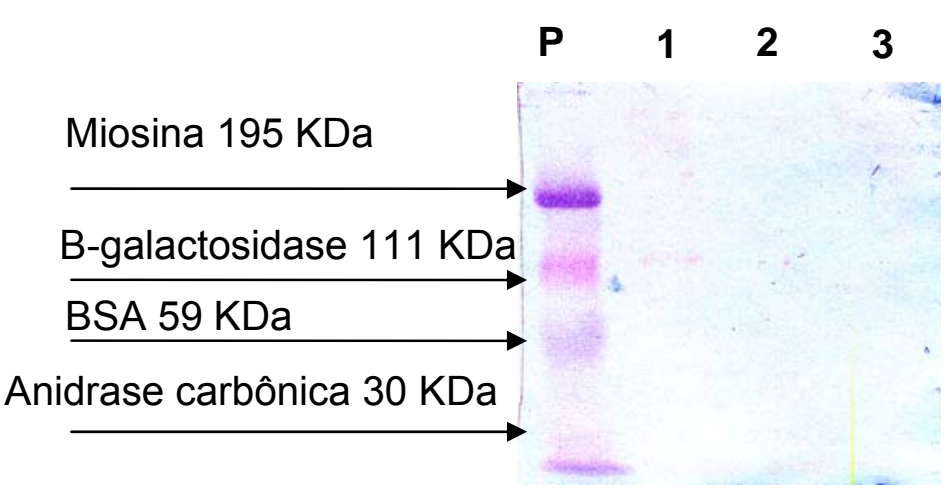

Figura14- Membrana de nitrocelulose corada com ponceau, mostrando o peso molecular kaleidoskope (PM) e as amostras do saco vitelínico de embriões bovinos (1 a 3). Em 1 embrião com período estimado de 30 a 40 dias, 2 com 40 a 50 dias e 3 de 50 a 60 dias de gestação. 
Para a técnica de Western Blot foi realizada eletroforese em gel de poliacrilamida com gel separador a $6 \%$ e stacking gel a $4 \%$, segundo o protocolo 3. Foram confeccionados dois géis. As amostras aplicadas, em seqüência foram: peso molecular Kaleidoskope ${ }^{R}$, fígado fetal, amostras dos embriões 5, 6, 7, 8, 9, 10, 11 e 12, no outro gel, peso molecular amostras dos embriões 13, 14, 15, 16 e 17. As amostras correram o gel por $110 \mathrm{~min}$, com os primeiros $20 \mathrm{~min}$ a $70 \mathrm{~V}, 80$ min a $100 \mathrm{~V}$ e os últimos $10 \mathrm{~min}$ a $120 \mathrm{~V}$. Após a transferência para as membranas de nitrocelulose, estas foram coradas com Ponceau (Figura 15 e 16). O bloqueio foi feito com leite $5 \%$. Reagimos a membrana com o anticorpo primário policlonal anti-coelho para alfa1- antitripsina 1:4, overnight, e com o anticorpo secundário conjugado para peroxidase 1:2000, durante uma hora. Após a revelação do tipo ECL, podemos observar algumas umas bandas (Figura 17 e 18) indicando assim que nessas amostras está presente a proteína alfa1-antitripsina na maioria das amostras, tendo uma maior reação nas amostras 3 e 9 que representam as amostras do saco vitelínico dos embriões 6 e 11 respectivamente. Esta proteína possui o peso molecular de aproximadamente $52 \mathrm{KDa}$, ficando entre a proteína BSA de 59 KDa e a proteína anidrase carbônica de 30 KDa. Essas mesmas membranas foram encubadas com o anticorpo primário para transferrina, overnight, na concentração 1:500 e depois com anticorpo secundário 1:2000 conjugado para peroxidase, durante uma hora. Após a revelação com ECl (figura 19 e 20) foram reativas em algumas amostras e nenhuma reação inespecífica foi observada devido a posição dessa proteína no gel, correspondendo ao peso molecular desejado. 


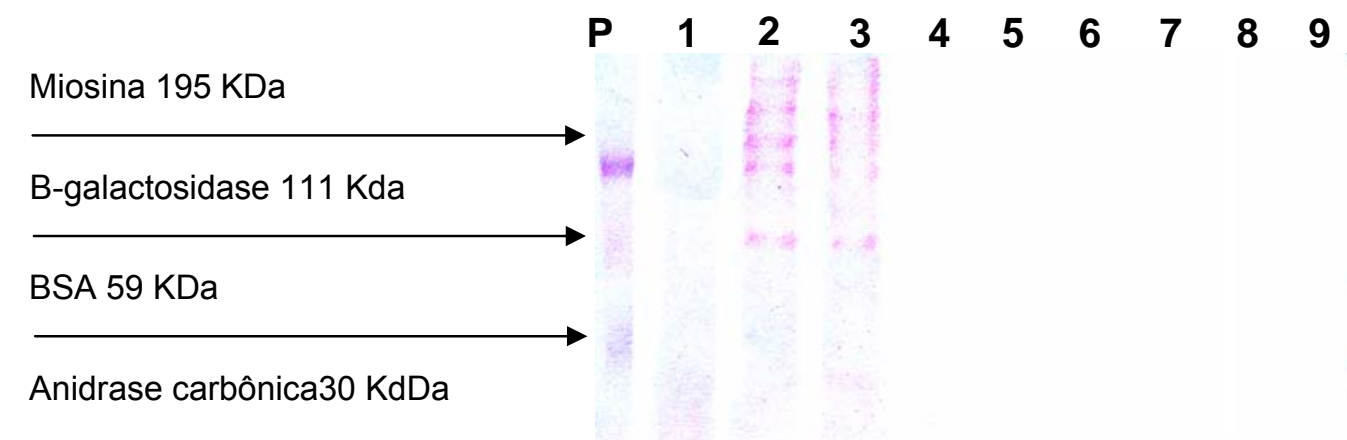

Fig 15- Membrana de nitrocelulose corada com ponceau, mostrando o peso molecular Kaleidoskope (PM) e as amostras do saco vitelínico de embriões bovinos (3 a 9). Em 1 amostra do fígado fetal, em 2, 3 e 8 embriões com período estimado de 30 a 40 dias, amostras 4 e 7 de 5 a10 dias, amostras 5 e 6 de 50 a 60 dias, amostra 9 de 20 a 30 dias de gestação.

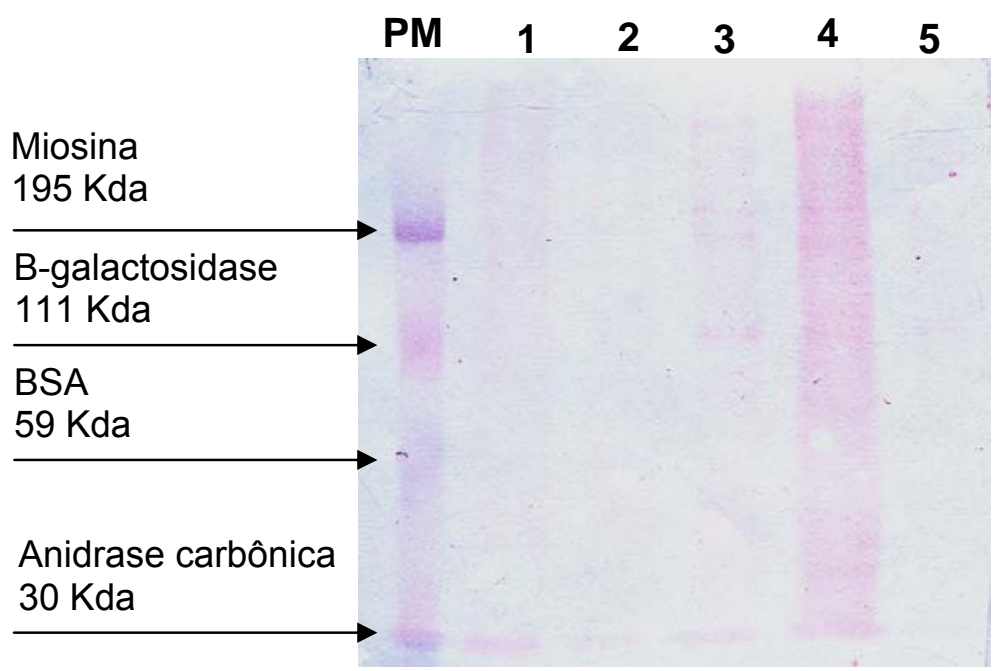

Figura16- Membrana de nitrocelulose corada com ponceau, mostrando o peso molecular kaleidoskope (PM) e as amostras do saco vitelínico de embriões bovinos (2 a 6) Em 2 , 3 e 4 embriões com período estimado de 30 a 40 dias, 5 com 40 a 50 dias e 5 de 50 a 60 dias de gestação. 


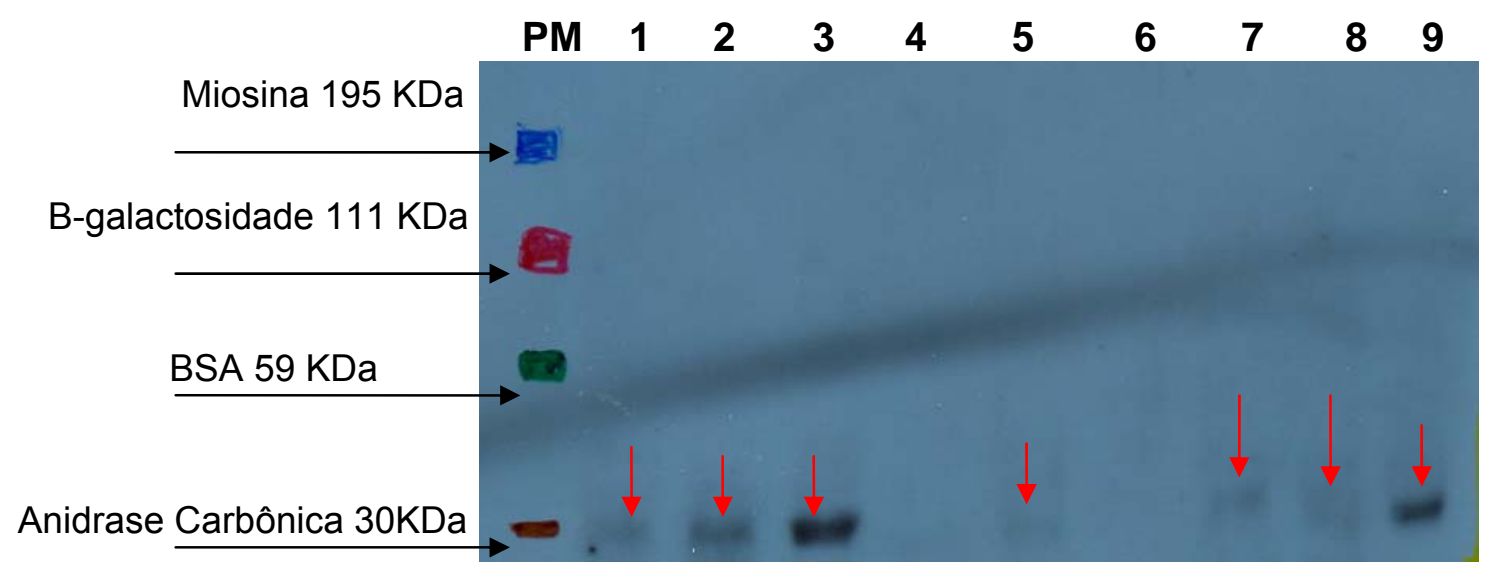

Figura17- Filme após a revelação do tipo $\mathrm{ECl}$, mostrando o peso molecular Kaleidoskope (PM) e as amostras do saco vitelínico de embriões bovinos (1 a 9).Em 1 amostra do fígado fetal , em 2, 3 e 8 embriões com período estimado de 30 a 40 dias, amostras 4 e 7 de 5 a10 dias, amostras 5 e 6 de 50 a 60 dias, amostra 9 de 20 a 30 dias gestação. As setas vermelhas indicam a proteína alfa- 1 antitripsina.

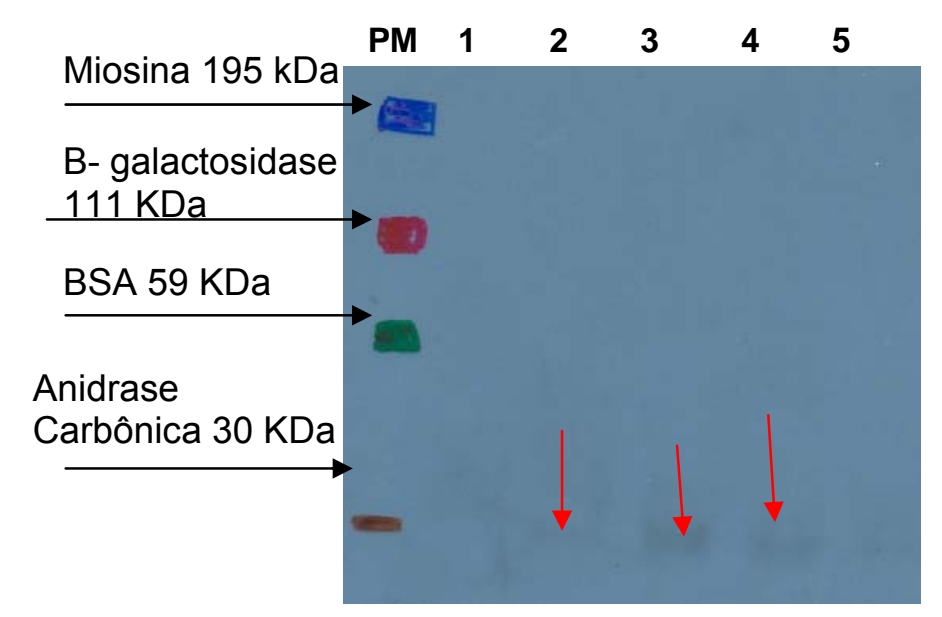

Figura18- Filme após a revelação do tipo $\mathrm{ECl}$, mostrando $O$ peso molecular kaleidoskope (PM) e as amostras do saco vitelínico de embriões bovinos (1 a 5). Em 1, 2 e 3 embriões com período estimado de 30 a 40 dias, 4 com 40 a 50 dias e 5 de 50 a 60 dias de gestação. As setas vermelhas indicam a proteína alfa-1 antitripsina. 


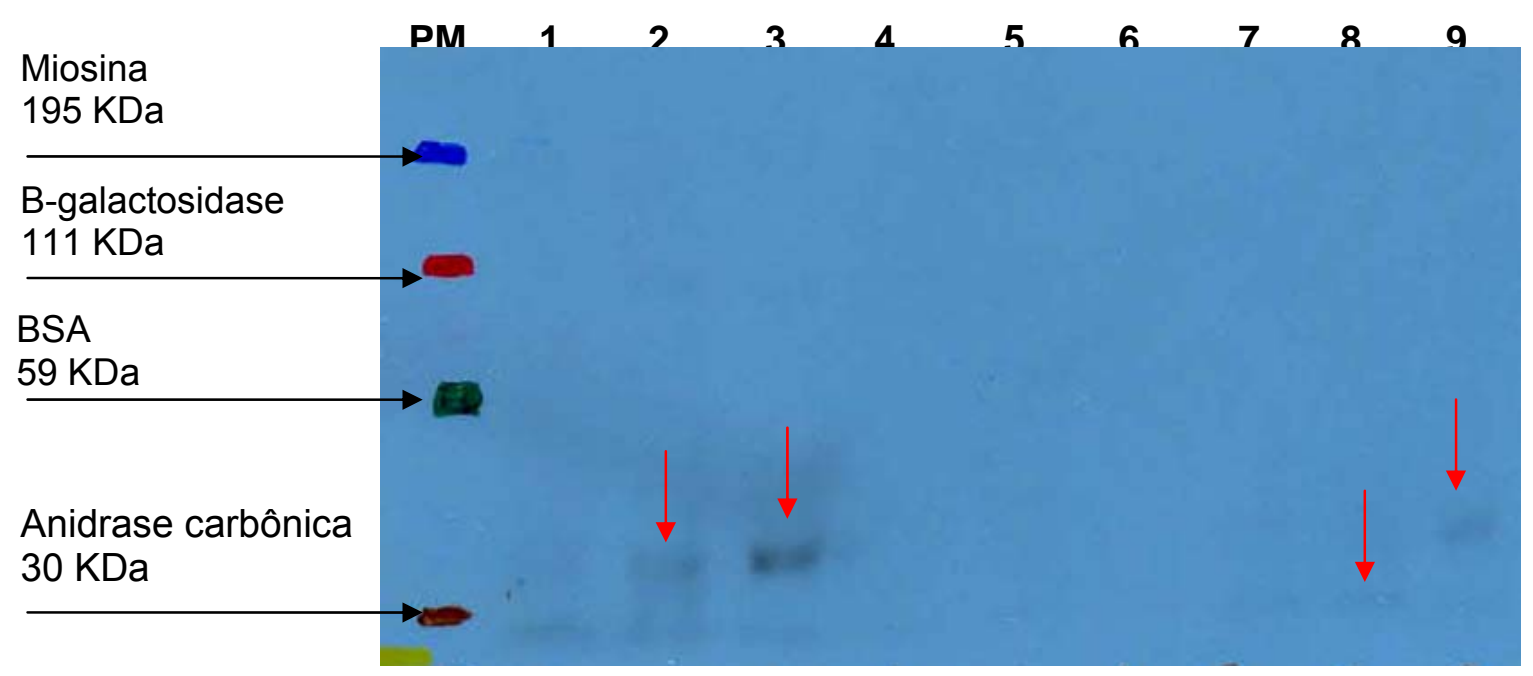

Figura19- Filme após a revelação do tipo $\mathrm{ECl}$, mostrando o peso molecular kaleidoskope (PM) e as amostras do saco vitelínico de embriões bovinos (3 a 9). Em 1 amostra do fígado fetal, em 2, 3 e 8 embriões com período estimado de 30 a 40 dias, amostras 4 e 7 de 5 a10 dias, amostras 5 e 6 de 50 a 60 dias, amostra 9 de 20 a 30 dias gestação. As setas vermelhas podem estar indicando uma reação inespecífica.

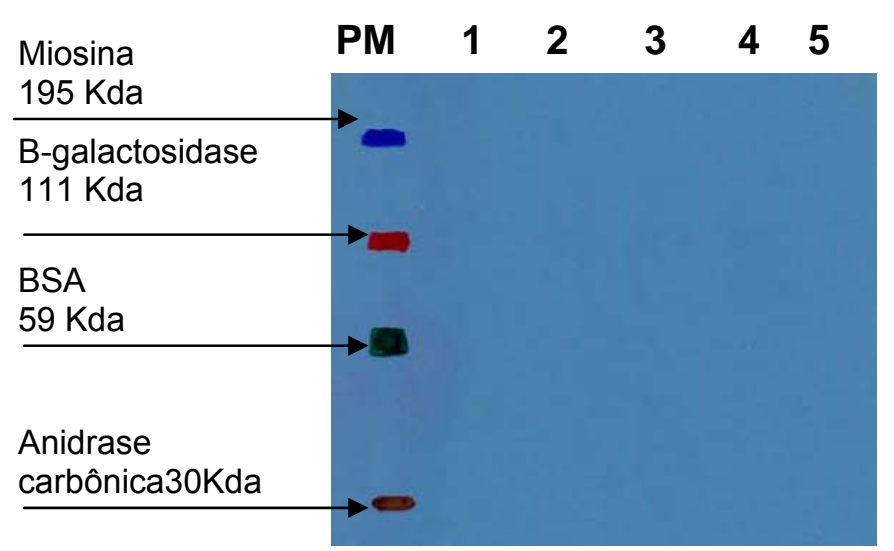

Figura 20- Filme após a revelação do tipo $\mathrm{ECl}$, mostrando o peso molecular (PM) e as amostras do saco vitelínico de embriões bovinos (1 a 5). Em em 1, 2 e 3 embriões com período estimado de 30 a 40 dias, 4 com 40 a 50 dias e 5 de 50 a 60 dias de gestação. 


\subsection{QUANTIFICAÇÃO DAS PROTEÍNAS}

A quantificação das proteínas foi realizada através do método de Bradford, onde as absorbância das diferentes concentrações de BSA, tomadas como padrões, estão indicadas na tabela 6 e, através dessas medidas construiu-se a curva padrão e a equação (Gráfico 1) utilizada para calcular a quantidade de proteínas presentes em cada amostra (tabela 7). As maiores concentrações protéicas estavam nas amostras do saco vitelínico dos embriões bovinos 5, 8, e 16 com período gestacional estimado entre 30-40 dias gestacionais, 50-60 dias e 4050 dias respectivamente, a maior concentração de proteínas esta nas amostra de fígado fetal

Tabela 6- Medidas das absorbâncias a 595 das diferentes concentrações de BSA.

\begin{tabular}{cc}
\hline Concentração BSA $(\mu \mathrm{g} / \mathrm{ml})$ & Absorbância a $595 \mathbf{n m}$ \\
\hline 0 & 0,003 \\
125 & 0,143 \\
250 & 0,226 \\
500 & 0,445 \\
750 & 0,583 \\
1000 & 0,924 \\
1500 & 1,012 \\
2000 & 1,177 \\
\hline
\end{tabular}


Gráfico 1 Curva padrão obtida através das diferentes concentrações de BSA e da absorbância a $595 \mathrm{~nm}$.

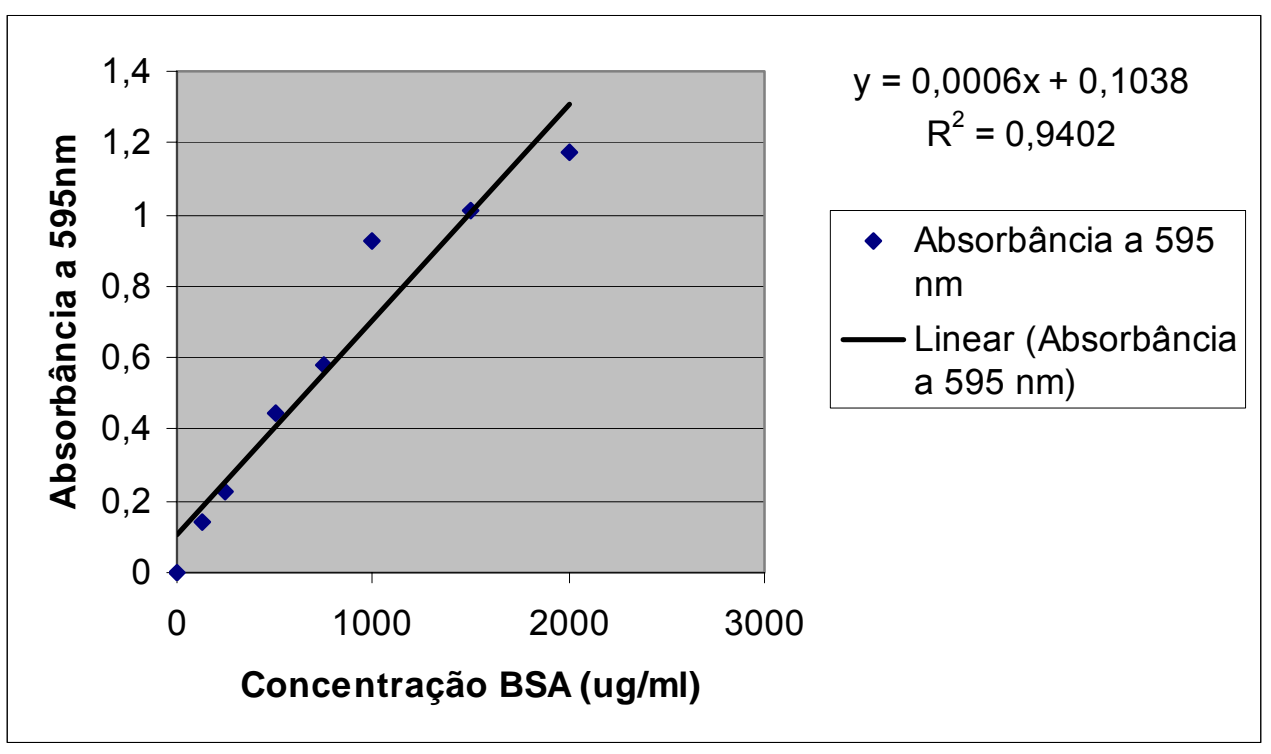

Tabela 7 Dosagem das proteínas das diferentes amostras de saco vitelínico de embrião bovino e suas absorbância a $595 \mathrm{~nm}$

\begin{tabular}{ccc}
\hline Amostras & Absorbância a 595 $\mathbf{~ m ~}$ & Concentração $\mathbf{u g} / \mathbf{m l}$ \\
\hline Fígado & 0,822 & 1197 \\
Embrião 05 & 0,666 & 937 \\
Embrião 06 & 0,536 & 720,33 \\
Embrião 07 & 0,536 & 720,33 \\
Embrião 08 & 0,599 & 825,33 \\
Embrião 09 & 0,193 & 148,66 \\
Embrião 10 & 0,397 & 488,66 \\
Embrião 11 & 0,519 & 692 \\
Embrião 12 & 0,555 & 752 \\
Embrião 13 & 0,528 & 707 \\
Embrião 14 & 0,467 & 605,33 \\
Embrião 15 & 0,368 & 440,33 \\
Embrião 16 & 0,548 & 740,33 \\
Embrião 17 & 0,441 & 562 \\
\hline
\end{tabular}




\section{DISCUSSAO}

Os itens discutidos estão relacionados ao período gestacional estimados dos embriões, a descrição macroscópica do saco vitelínico, ao método e protocolos utilizados na análise das proteínas, bem com seus resultados.

\subsection{DESCRIÇÃO MACROSCÓPICA DO SACO VITELÍNICO}

Os períodos gestacionais foram estimados conforme metodologia preconizada por Evans e Sack (1973) e Noden e Lahunta (1972) com mensuração da distância occípto-sacral, tomando como referência a crista nucal numa extremidade e a última vértebra sacral na extremidade oposta (Crown - Rump / CR). De acordo com as medidas obtidas os embriões foram agrupados, em 6 períodos gestacionais diferentes. Analisando a tabela descrita por Evans e Sack (1973) e Noden e Lahunta (1972), as medidas de CR possuem valores aproximados às medidas descritas nesse trabalho, mas por falta de uma literatura mais recente e mais detalhada não podemos afirmar o período gestacional exato de cada embrião.

Em nossos achados, o saco vitelínico, uma membrana fina e transparente, mostra-se bastante desenvolvido até 40 dias de gestação, estando próximo aos vasos umbilicais do embrião e conectado ao intestino do embrião. O seu tamanho diminui drasticamente, ficando difícil sua visualização a partir dos 50 dias de gestação, onde o processo de involução está bem caracterizado, tornando-se uma membrana bem fina e transparente.

Segundo estudos realizados por Barone (1976) o saco vitelino involui e degenera-se muito cedo nos ruminantes, e a partir da segunda semana seus vestígios não são encontrados até o final da prenhez. 
Latshaw (1987) descreve que o saco vitelino de mamíferos domésticos é inicialmente grande, mas ele regride quando a placenta permanente se desenvolve. Embora este seja uma estrutura transitória, o saco vitelínico tem várias funções importantes como nutrir a placenta permanente até que a mesma esteja formada, sendo especialmente importante nos eqüinos e carnívoros. Inicialmente o saco vitelínico é grande e vascular, sendo completamente envolvido pelo celoma, separado do cório e completamente vascularizado ao redor do $20^{\circ}$ dias de gestação na vaca, apresentando apenas uma existência transitória, pois é precocemente deslocado pelo rápido crescimento do saco alantóide. As mesmas observações foram feitas por Bryden, (1972) e Noden; Lahunta, (1972) onde observam que em ruminantes o saco vitelino é grande e vascularizado e está completamente solto do cório ao redor do $20^{\circ}$ dia de prenhez na vaca. Ao redor do $25^{\circ}$ dia de prenhez, fica reduzido a uma estrutura sólida como um cordão. Em mamíferos domésticos é transitório, entretanto tem grande importância em realizar trocas embrionárias e maternas antes que placenta permanente estivesse formada. Conforme a cavidade se expande, a área de transferência efetiva da placenta vitelina diminui e quando a formação da cavidade extraembrionária está completa, a separação do mesoderma no ponto de fixação entre o saco vitelínico e o cório é destruída. Nesta hora, uma placenta vitelina não mais existe.

\subsection{ANÁLISE DAS PROTEÍNAS}

$\mathrm{Na}$ literatura consultada pouco foi encontrado referente à presença dessas proteínas no saco vitelínico de embrião bovino. As maiores descrições são referentes às proteínas produzidas pelo saco vitelínico humano e de camundongos.

Segundo Liu et al. (1991) o saco vitelínico do camundongo produz especificamente proteínas idênticas as proteínas do soro fetal de bovinos como a transferrina, $\propto_{1}$-fetoproteina, $\propto_{1}$-antitripsina, $\propto_{1}$-glicoproteína ácida. De acordo com Thomas et al. (1990) o saco vitelínico visceral e o fígado fetal de camundongo 
sintetiza proteínas como transtiretina, transferrina e $\propto_{1}$-fetoproteína mas uma maior quantidade dessas proteínas é produzida pelo saco vitelínico no início da gestação.

Em estudos realizados por Gitlin e Perricelli (1970), o saco vitelínico de coelhos produz proteínas como: prealbumina, albumina, a transferrina, $\propto_{1}$

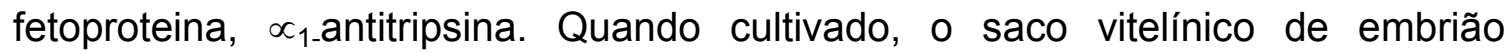
humano, com 5-5 semanas de gestação, apresenta grandes quantidades das

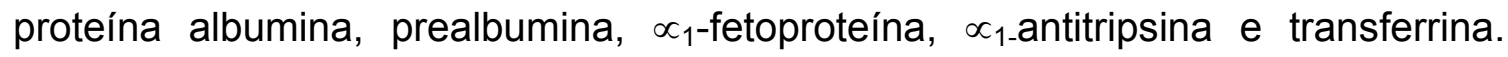
Quantidades um pouco menores estaão presentes na cultura de saco vitelínico de embrião com 8-5 semanas de gestação e na cultura de embriões de 11-5 semanas encontra-se prealbumina e uma pequena quantidade de albumina, $\propto_{1}$ -

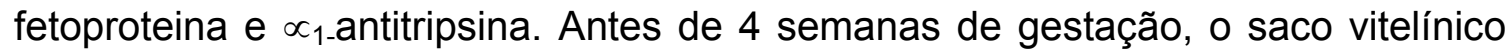
humano apresenta-se como uma vesícula bem definida e o fígado por brotos e ductos hepáticos que sintetizam, prealbumina, albumina, $\propto_{1}$-fetoproteína, $\propto_{1}$ antitripsina e transferrina, além de outras proteínas.

Pouco se sabe a respeito das proteínas sintetizadas sobre o saco vitelínico da espécie bovina, portanto utilizamos nesse trabalho as referências que dizem respeito às proteínas produzidas pelo saco vitelínico de camundongo e humanos para selecionar as proteínas em estudo.

O saco vitelínico é reconhecido, por muito tempo, por ter a função hepática fetal tal como a hematopoiese, e a produção de proteínas durante o início do desenvolvimento embrionário (LIU et al., 1991). Farrington, Belaourssoff e Baron (1997) descrevem algumas funções vitais do saco vitelínico visceral para crescimento e diferenciação embrionária, tais como, absorção e digestão de nutrientes maternal, síntese de proteínas, formação da circulação vitelínica e secreção intravascular de nutrientes.

De acordo com Meenhan et al. (1984) e Gulbis et al. (1998), o saco vitelínico pode executar muitas funções do fígado no desenvolvimento embrionário antes da maturação do fígado fetal, além sintetizar uma variedade de proteínas em comum ao fígado fetal. Proteínas secretadas por essa membrana são capazes de entrarem na circulação fetal. Embora o saco vitelínico secrete proteínas 
protoplasmáticas, não se sabe ainda a direção desta secreção (THOMAS et al., 1990). Devido aos descritos acima, onde o saco vitelínico embrionário produz proteínas semelhantes ao fígado fetal, achou-se necessário o uso de fígado fetal bovino como controlo positivo das amostras para a técnica de Western Blot, pela falta do controle positivo humano.

Em nossos estudos, após a corrida e transferência em SDS-PAGE alguns resultados mostram-se não reativos com os anticorpos específicos utilizados. Provavelmente o resultado negativo obtido resultante do protocolo II, está relacionado ao tempo elevado de corrida das amostras (3 horas) prejudicando assim a análise dos resultados, pois as proteínas de interesse são proteínas de peso molecular pequeno. Talvez, padronizar a corrida e a transferência, aumentando o tempo e diminuindo a voltagem, possa melhorar os resultados. Para garantia da corrida do gel em relação ao tempo utilizado, poderá ser feito o uso da colação com Nitrato de prata, cuja sensibilidade é superior ao do Comassie Blue, para assim observar melhor os padrões de peso molecular, ou modificarmos a concentração da malha de acrilamida no gel e passarmos para 10-15\%.

Segundo Bradford (1976) a coloração por Comassie Blue, trata-se de um método simples e rápido baseado na utilização do radioativo azul de Comassie Blue em condições ácidas, que formam complexos apenas com proteínas, onde seu pico de absorção é de 465 a $595 \mathrm{~nm}$.

Segundo Sigma (P3504) o corante Ponceau é usado para marcar de forma rápida faixas de proteína em membranas de nitrocelulose PVDF e membranas de acetato de celulose. Esses corantes foram usados para comprovar se nas amostras utilizadas realmente havia proteínas, sendo estas indicadas pelas bandas.

Em nossos estudos, em algumas amostras, observamos a presença de algumas proteínas em amostras do saco vitelínico de embriões bovinos.

Nos nossos resultados a AFP apresenta um peso molecular próximo ao peso molecular da proteína $\beta$-galactosidase que é uma proteína com $111 \mathrm{KDa}$, estando próximo ao peso molecular estudado por alguns autores que varia de 69 a 72 KDa. Gulbis et al. (1998) descrevem esta proteína humana como tendo peso 
molecular de 70KDa, peso este bem próximo ao analisado por Milunsky (1992) e Daffos e Forestier (1988) de 69 KDa e por Alpert de 72 KDa. Em relação ao teste feito com o anticorpo primário monoclonal anti-camundongo para alfafetoproteína humana, (SERO- MCA1863HT- $1 \mathrm{ml}$ ), com a não reação com as outras amostras, podemos supor que as demais amostras não possuem esta proteína ou que este anticorpo primário tenha estragado fato este difícil de acontecer. Outros testes realizados com o outro anticorpo primário monoclonal anti-camundongo para alfafetoproteína humana, (Vector laboratories, VP-A104), também não houve reação, como este anticorpo não foi testado em Western Blot, não podemos garantir que funcionasse em nossas amostras.

Segundo Gulbis et al., (1998) a AFP (alfafetoproteína) é uma glicoproteína embrionária produzida no segundo mês de gestação pelo saco vitelínico visceral, pelo fígado fetal e pelo trato gastrointestinal, saco vitelínico e em menor quantidade pelo fígado fetal, sendo a principal glicoproteína plasmática sintetizada durante o desenvolvimento pelos hepatócitos. Durante a gestação, cruza a via placenta ou fluido amniótico do feto para a mãe (HAU, et al., 1981). Estudos realizados por Milusnsky (1992) e Daffos (1988) esta proteína é sintetizada pelo saco gestacional (vesícula vitelínica), trato gastrointestinal e principalmente pelo fígado fetal, mas, pequenas quantidades podem ser produzidas pelos rins e placenta. De acordo com Zizkovsky (1975) a AFP é uma proteína sintetizada pelo saco vitelínico e fígado fetal da maioria dos mamíferos, com função ainda desconhecida. A função biológica da alfafetoproteína no feto ainda permanece desconhecida. Acreditava-se apenas em uma função imunológica envolvida na prevenção da rejeição do feto pela mãe (DAFFOS 1988) Yachinin, Soetani e Lester (1980) concluem que a AFP é imunosupressiva. Gorin et al. (1981) estudou que em fetos essa proteína pode ser comparável à albumina sérica de adultos, sendo a principal proteína para o desenvolvimento do feto, sendo sintetizada pelo fígado e saco vitelínico embrionário. Depois do nascimento as concentrações da AFP diminuem dràsticamente aos níveis que são mal detectáveis em adultos nãogestantes. A queda do nível dessa proteína resulta em uma diminuição gradual de sua taxa sintetizada pelo fígado e, no exemplo dos roedores, pela perda do saco 
vitelínico Entretanto, a síntese de AFP é recomeçada no fígado adulto durante a sua degeneração, e em tumores específicos tais como hepatomas e teratocarcinomas. Descreve ainda que há similaridades estrutural e funcionais entre AFP e albumina, que levou à sugestão que a AFP servia como uma albumina fetal. As concentrações elevadas de AFP e de albumina no plasma ajudam no controle do plasma e da pressão osmótica do líquido intravenoso. $A$ AFP esta relacionada também a uma resposta imune da mãe e da proteção do feto, em roedores, dos efeitos de estrógenos maternal. Lowset et al., (1991) comenta que esta proteína atua na proteção das células neurais dos altos níveis de estrógenos durante o desenvolvimento fetal. Observa ainda que o nível da AFP apresenta valores significantemente aumentos no carcinoma hepatocelular e em tumor de células embrionárias humanas e animais, o que auxiliam na realização do diagnóstico e monitoramento de resposta e terapias.

Nas amostras do saco vitelínico do embrião bovino 6 (período gestacional estimado entre 30 a 40 dias), 8 (entre 50 a 60 dias) e 10 (entre 0 a 15 dias) foi detectada a presença da proteína transferrina, estando próxima a proteína $\beta$ galactosidade de peso molecular $111 \mathrm{KDa}$. Como o anticorpo não é especifico isto pode ter dificultado porque o mesmo provavelmente faz uma fraca reação cruzada com a proteína bovina. Já no fato de aparecerem bandas inespecíficas quando reagimos a membrana com este anticorpo, talvez esse fato possa ser explicado devido ao tempo de bloqueio. Segundo Brock et al. (1976) esta proteína de peso molecular de $85 \mathrm{KDa}$ essencialmente sintetizada pelo fígado e está envolvida no transporte de ferro e quando cultivada in vitro mostra um efeito bacteriostático, e em experiências in vivo sugere que este mecanismo pode contribuir para defesas contra bactérias patogênicas, indicando assim uma outra possível função fisiológica dessa proteína. De acordo Streu et al. (2000) a transferrina, uma glicoproteina presente em altas concentrações no fluido amniótico, realiza o transporte de fero durante a prenhez, suprindo o aumento da demanda fetal de ferro. Sugere ainda que essa glicoproteína tenha influência no controle da produção de progesterona, modulando a função endócrina dos trofoblastos. E de acordo com Carlson (1994), a superfície placentária possui receptores específicos 
para essa proteína. Aparentemente, o ferro desloca-se da transferrina na superfície placentária, sendo então ativamente transportado para os tecidos fetais.

Observamos que na maioria das amostras (amostras do saco vitelínico dos embriôes bovinos $5,6,7,9,11,12,14,15$ e 16) há reação do anticorpo humano com a proteína bovina, esta reação mostra-se mais forte mas amostras 3 e 9 que representa os embriôes com período gestacional de 0 a 15 dias e 20 a 30 dias respectivamente, esta proteína encontra-se com peso molecular próximo ao da anidrase carbônica de 30KDa. Segundo Aires (1999), a alfa-1-antitripsina (A1AT), uma glicoproteína de peso molecular de $52 \mathrm{KDa}$ produzida principalmente pelos hepatócitos libera diariamente cerca de $2 \mathrm{~g}$ da proteína na circulação. A principal função da A1AT é inibir a elastase neutrofílica, uma protease de serina que tem a capacidade de hidrolisar as fibras de elastina no pulmão. Esta enzima inibe a ação de outras enzimas que quebram as proteínas. A deficiência de alfa1-antitripsina permite que as demais enzimas lesem os tecidos pulmonares. Segundo Takashina et al. (2004) a A1AT é um inibidor de protease produzido por células epiteliais do âmnio no período gestacional e pelos hepatócitos ao longo de todo a vida do indivíduo. Vatine et al. (1996) comprova que a A1AT agia como inibidor das proteínas elastase e tripsina, porém em sítios de ligações diferentes. Observa também sua importância em processos inflamatórios pulmonares, onde possue a capacidade de inibir a migração de macrófagos alveolares. A deficiência desta proteína, com causa ainda desconhecida desencadeia manisfestações clínicas de diferentes graus, como cirrose hepática, doenças obstrutivas crônicas e enfisemas pulmonares, e até mesmo paniculites. Essa deficiência pode ser diagnosticadano período de gestação, em humanos, para avaliação do nível desta proteina (RICHMOND; ZELLNER, 2005).

Não podemos afirmar o tamanho das proteínas em estudo, foram reveladas bandas, que podem estar com outra especificidade, com outro peso molecular, pois os anticorpos primários utilizados, não são específicos ás proteína, desta maneira, as bandas observadas poderiam ser cadeias ou dímeros das proteínas em estudo. 


\section{CONCLUSÃO}

Os anticorpos primários utilizados, baseados nas proteínas humanas podem detectar as proteínas bovinas pela técnica de Western Blot

Detectou-se a proteína alfafetoproteína em algumas amostras do saco vitelínico de embriões bovinos, mostrando que há reação do anticorpo antihumano com a proteína bovina.

A alfafetoproteína presente no embrião garante sua sobrevivência e posterior desenvolvimento, pois diminui a atividade do sistema imunológico materno impedindo que a mãe considere o embrião como corpo estranho e combata a sua existência.

Detectou-se também a proteína transferrina e a antitripsina em algumas amostras do saco vitelínico de embriões bovinos, mostrando que, provavelmente estes anticorpos fazem uma fraca reação cruzada com a proteína bovina, por não serem específicos.

A transferrina, com função de transporte e armazenamento de ferro, impede a utilização do mesmo por microorganismo indesejados que possam interferir no desenvolvimento embrionário, alem de possuir efeito bacteriostático, impedindo a multiplicação e conseqüente colonização bacteriana, impossibilitando assim a ocorrência de uma infecção fetal que poderia prejudicar o desenvolvimento embrionário.

A alfa 1-antitripsina, com função de inibir a elastase neutrofília impede que essa enzima lese os tecidos pulmonares, garantindo assim o desenvolvimento pulmonar do embrião. 
REFEREิENCIAS 


\section{REFERÊNCIAS}

AIRES, M. M. Fisiologia. 2. ed. Rio de Janeiro:Guanabara Koogan:,p. 706, 1999

ALBERTS, B.; BRAY, D.; KAREN, H.; JONSHON, A.; LEWIS, J.; RAFF, M.; ROBERTS, K.; WATER, P. Fundamentos da biologia celular. 2. ed. Porto Alegre: Artmed, p. 866. 2006.

ALMEIDA, J. M. Embriologia veterinária comparada. 1. ed. Rio de Janeiro: Guanabara Koogan, p. 156. 1999

ALPERT, P.; DRYSIDALE, J. W.; ISSELBACHER, K. J.; SCHUR, P. H. Human afetoprotein: Isolation, characterization, and demonstration of microheterogeneity. Journal of Biological Chemistry, v. 247, n. 12, p. 3792-3798, 1972.

ALVES, D. F.; RAUBER, L. P.; RUBIN, F. B.; BERNARDI, M. L.; SILVA, C. A. M.; RUBIN, M. I. B. Desenvolvimento embrionário in vitro de oócitos bovinos mantidos em líquido folicular ou TCM-hepes. Brazilian Journal of Veterinary Research and Animal Science, v. 40, n. 4, p. 279-286, 2003.

ARTHUR, G. H. Reprodução e obstetrícia em veterinária, 4 ed. Rio de Janeiro: Guanabara Koogan,.p. 573. 1979

ASSIS NETO, A. C. Desenvolvimento placentário em bovinos obtidos por gestações naturais e por fecundação in vitro. 2005. 223 f. Tese (Doutorado) Faculdade de Medicina Veterinária e Zootecnia, Universidade de São Paulo, 2005.

BACHA, W. J.; BACHA, L. M. Atlas colorido de histologia veterinária. 2. ed. São Paulo:Roca, p. 457, 2003 
BARONE, R. Anatomie comparèe dês mammifères domestiques. Splanchnologie. Paris: Vigot Frères, t. 2, p. 579-605. 1976

BERG, J. M.; TYMOCZKO, J. L.; STRYER, L. Bioquímica. 5 ed. Rio de Janeiro: Guanabara Koogan,.p. 1059. 2004

BEZERRA, L. R. Biblioteca virtual de tropicologia - Pecuária e Tropico, v.2, p. 606-624, 1976. Disponível em: www.tropicologia.org.br. Acessado em fevereiro de 2005.

BJÖRKMAN, N. Fine structure of the fetal-maternal area of change in the epithelial and endothelial types of placentation. Acta Anatomica, v. 86, p. 1-22, 1973. Suplemento 1.

BOWEN, J. A.; BURGHARDT, R. C. Cellular mechanisms of implantation in domestic farm animals. Cells \& Developmental Biology, v. 11, p. 93-104, 2000.

BRADFORD, M. M. A rapide and sensitive method for the quantitation of microgran quantities of protein utlizing the principle of protein dye binding. Analytical Biochemestry. v.72, p. 248-254, 1976.

BROCK, J. H.; ARZABE, F.; LAMPREAVE, F.; PINEIRO, A. The effect of trypsin on bovine transferring and lactoferrin. Biochimica of Biophysica Acta, v. 446, p. 214-225, 1976.

BRYDEN, M. M.; EVANS, H. E.; BINNS, W. Embryology of the sheep: Extraembryonic membranes and the development of body form. Journal Morphology, v. 138, n. 2, p. 169-185, 1972. 
CARLSON, B. M. Embriologia humana e biologia do desenvolvimento. Rio de Janeiro:Guanabara Koogan, p. 408. 1994

COSTA, A. C. Manual de embriologia. 2. ed. Rio de Janeiro:Livraria Luso Espanhola e Brasileira, p. 342. 1957

DAFFOS F, FORESTIER F. Biologie du Sang Foetal. In Daffos F, Forestier F eds. Médecine et Biologie du Foetus Humain, Paris:Maloine, p. 79-123. 1988.

DRIEUX, H. THIERY G. La placentation chez las mamiféres domestiques III. Placenta dês Bovides. Recueil de Medecina Veténaire, v. 127, n.1, p 5-25, 1951.

EVANS, H. E.; SACK, W. O. Prenatal Development of Domestic and Laboratory Mammals: Growth Curves, External Features and Selected References. Anatony and Histology and Embryology, v. 2, p. 11-45, 1973.

EVENSON, M. A. Aparelhos utilizados no laboratório: fundamentos técnicos e discrição geral. In: Henry, J. B. Diagnósticos clínicos e conduta terapêutica por exames laboratoriais- Todd. Santord. Davidshon. 16. ed. São Paulo: Manole. 1982, v.1, cap. 4, p. 81-114.

FARRINGTON, S. M.; BELAOUSSOFF, M.; BARON, M. H. Winge-Helix, hedgehod and Bmp genes are differentially expressed in distinct cell layers of the murine yolk sac. Machanisms of Development, v. 62, p.197-211, 1997.

FILHO, A. M. Reprodução dos animais. 6.ed. Porto Alegre:Sulina. p. 314, 1987.

GARCIA, S. M. L.; FERNANDEZ, C. G. Embriologia. 2.ed. São Paulo:Artmed, p. 408, 2001. 
GITLIN D.; PERRICELLI A. Synthesis of Serum Albumin, Prealbumin, $\propto-$ Foetoprotein, $\propto_{1}$ - Antitrypsin and Transferrin by the Human Yolk sac. Nature, v. 228, p. 995-997, 1970.

GODKIN, J. D.; LIFSEY, B. J.; BAUMBAUCH, G. A. Characterization of protein production by bovine chorionic and allantoic membranes. Biology of Reproduction, v. 39, p.195-204, 1988.

GORIN, M. B.; COOPER, D. L.; EIFERMAN, F.; RIJN, P.; TILGHMAN, S. M. The evolution of $\alpha$-fetoprotein and albumin. Journal of Biological Chemistry, v. 256, n. 4, p. 1954-1959, 1981.

GULBIS B.; JAUNIAUX, E.; COTTON, F.; STORDEUR, P. Protein and enzyme patterns in the fluid cavities of the first trimester gestacional sac: relevance to the absorptive role secondary yolk sac. Molecular Human Reproduction, v.9, p. 857862, 1998.

HAFEZ, B.; HAFEZ, E. S. E. Reprodução animal. 7.ed. São Paulo:Manole,.p. 513,2004

HAU, J.; SVENDSEN.; TEISNER, B.; PEDERSON, T. G.; KRISTIANSEN, B. Correlation between fetal weight and maternal serum levels of murine $\propto$ foetoprotein and quantitation of four molecular forms. Biology of Reproduction, $v$. 24, p. 683-689, 1981.

JONHANSSON, B. G. Agarose gel electrophoresis. Scand. Journal. Clinical. Laboratoris. Invest., v. 29, p. 7-19, 1972. Suplemento 124.

JUNQUEIRA, L. C. e CARNEIRO, J. Histologia básica, 7ed. Rio de Janeiro: Ganabara Koogan, p. 388, 1990. 
KANEKO, J. J. Serun proteins and the dysproteinimias. In: Kaneko JJ, Harvery JW, Bruss ML. Clinical Biochemistry of Domestics Amimals. 5 ed. San Diego: Academic Press; p. 117-38, 1989.

KAUFMANN, P.; DAVIDOFF, M.. The guinea pig placenta. Advances in Anatomy Embryology and cell Biology, v. 53, n.2, p. 5-90, 1977.

KING, B.; ENDERS, A. Protein absorption and transport by the guinea pig visceral yolk sac placenta. The American journal of anatomy, v. 129, p. 261-88, 1970.

KING, B. F. Comparative anatomy of the placenta barrier. Bibliotheca anatomica. n.22, p. 13-28, 1982.

LAEMMLI, U. K. Cleavage of structural proteins during the assembly of the head bacteriophage T4. Nature, v. 227, p. 680-685, 1970.

LATSHAW, W. K. Veterinary developmental anatomy: A clinical oriented approach. Toronto: Decker, p. 49-79, 1987.

LEISER, R.; KAUFMANN, P. Placenta Structure: in a comparative aspect experimental and clinical. Endocrinology, v. 102, n. 3, p. 122-134, 1994.

LOWSETH, L. A.; GILleTt, N. A.; CHANG, I. Y.; MUGGENBURG, B. A.; BOECKER, B. B. Detection of serum alpha-fetoprotein in dogs with hepatic tumors. Journal of the American Veterinary Medical Association. v. 199, n. 6 , p. $735-741,1991$.

LIU, K. H.; BREWTON, R. G.; BAUMBACH, G. A. GODKIN, J. D. Characterization of protein production by ovine placental membranes: Identification of a placental retinal-bilding protein. Endocrynology, v.129, p.126-132, 1991. 
LIU, K. H.; HUANG, J. C; GODKIN, J. D. Characterization of protein production by caprine placental membranes: indentification and immunolocalization of retinalbilding protein. Journal of Endocrinology, v.146, p.527-534, 1995.

MARZZOCO, A.; TORRES, B. B. Bioquímica Básica. 2ed. Rio de Janeiro Guanabara Koogan, p. 360. 2001.

MEEHAN, R. R.; BARLOW, D. P.; HILL, R. E.; HOGAN, B. L. Pattern of serum protein gene expression in mouse visceral yolk sac and foetal liver. EMBO Journal, v. 3 , p. $1881-1885,1984$.

MELVIN, M. Electrophoresis: Analytical chemistry by open learning. London: John Wily \& Sons, 1987. 130 p.

MILUNSKY A. Maternal Serum Screening for Neural Tube and Other Defects. In Milunsky A ed. Fetus: Diagnosis, prevention and treatment. 3 ed. Baltimore:The Johns Hopkins University Press, p. 507-63. 1992.

MOSSMAN, H. W. Vertebrate fetal membranes. New Brunswick: Rutgers University Press, p. 383, 1987.

NAOUN, P. C. Eletroforese- Técnicas e diagnósticos. São Paulo:Santos, 1990

NODEN, D. M.; LAHUNTA, A. Embriologia de los animales domésticos mecanismos de desarrollo y malformaciones. Zaragoza: Acribia, 1972.

RICHMOND, R. J.; ZELLNER, K. M. Alfa 1-antitrypsin deficiency: incidence and implications. Dimensions of Critical Care Nursing, v. 39, n. 6, p. 255-256, 2005.

RÜSSE, I.; SINOWATZ, F.; RICHTER, L. LEHMANN, M.; SCHALLENBERGER, E. Die Entwichlung des Dottersacker blin wiederkäauer (Schaf und Rind). Anatomy and Histology and Embryology. Berlin, v.21, p. 324-347, 1992. 
SALESBURY, G. W.; VANDERMARK, N. L. Fisiologia de la reproduccion e inseminacion artificicial de los Bovidos. 1. ed. Zaragoza:Acribia, p. 705, 1964.

STREU, A.; JESCHKI, U.; RICHTER, D. U.; MULLER, H.; BRIESE, V.; FRIESE, K. Human amniotic fluid with transferrin stimulates progesterone production by human trophoblast cells in vitro. Zentralbl Gynakol, v. 122, n. 8, p. 407-412, 2000.

TAKASHINA, S.; ISE, H.; ZHAO, P.; AKAIKE, T.; NIKAIDO, T. Human amniotic epithelial cells posses hepatocite-like characteristics and functions. Cell $\underline{\text { Structure }}$ and Function. v. 29, n. 3, p. 73-84, 2004.

THOMAS, T.; SOUTHWELL, B. R.; SCHREIBER G.; JAWORROWSKI A. Plasma protein síntesis and secretion in the visceral yolk sac of the fetal rat: gene expresión, protein síntesis and secretion. Placenta, v. 11, p. 413-430, 1990.

VATINE, M.; ANDERSON, M.; SERELIUS, E.; JONSSON, L. Elastaseinibitory capacity of purified canine alpha-1-antitrypsin. Journal of Comparative Pathology, v. 114, n. 3, p. 211-219, 1996.

VOSS, A. Eletroforese. LAES/HAES, v.8, p. 69-75, 1987

WOLF, E. Et al. Embryo-maternal communication in bovine- strategies for deciphering a complex cross-talk. Reproduction in Domestic Animal, v.38, p. 276289, 2003.

YACHNIN, S.; SOLTANI, K.; LESTER, E. P. Further studies on the machanisms of suppression human lymphocyte transformation by human alpha-fetoprotein. Journal of Allergy and Clinical Immunology. v. 65, p. 127-135, 1980. 
ZAHA, A.; FERREIRA, H. B.; PASSAGLIA, L. M. P. Biologia molecular básica. Porto Alegre:Mercado Aberto, p. 424, 2003.

ZIZKOVSKY, V. Specific fetal serum protein of thirteen mammalian species. Comparative Biochemistry and Physiology. v. 51B, p. 87-91, 1975. 